\title{
Azerbaycan Cumhuriyeti’nin Devlet Yönetimi Yapısı ve Siyasal Sistemi
}

\author{
The Public Administration Structure and Political System of The Republic of Azerbaijan
}

\section{Recep REHIMLI}

Doç. Dr., Azerbaycan Cumhurbaşkanliğına Bă̆lı

Devlet Idarecilik Akademisi,

Kamu Personel Yönetimi Bölümü,

rehimli@yahoo.com

https://orcid.org/0000-0003-1414-0031
Makale Başvuru Tarihi: 28.04.2020

Makale Kabul Tarihi: 07.09.2020

Makale Türü: Araştırma Makalesi

\begin{abstract}
Anahtar
Kelimeler:

Azerbaycan Kamu

Yönetimi,

Başkanlık Sistemi,

Kamu Personel

Sistemi,

Siyasi Partiler,

Kamu Yönetimi

Reformlart.
\end{abstract}

Keywords:

Azerbaijan Public

Administration,

Presidential System,

Public Personnel

System,

Political Parties,

Public

Administration

Reforms,

\section{ÖZET}

SSCB'nin çökmesinden sonra yeniden bă̆ımsızlık kazanan Azerbaycan Cumhuriyeti'nde, devletin yönetsel yapılanması ve demokratikleşme alanında reformlara başlanıldı. Bu reformlar bir bütün olarak kamu yönetimi alanında bir dizi önemli yenileșimleri beraberinde getirdi. Bunlardan en önemlilerinden olarak, yeni bir anayasanın kabulü, kamu yönetimi sisteminde etkinliyin ve verimliliyin artırllması yönünde yenilikçi adımların atılması, devletin sosyal, politik, hukuki, ekonomik ve ideolojik işlevlerinin değişimini belirtebiliriz. Bu kapsamda önceki rejimden kalma birçok kurumlar kaldırıld, modern yönetim sistemine uyum sağlayabilecek yeni kurum ve kuruluşlar tahsis edildi ve yönetim sisteminin etkinliğini artırmak için birçok hukuki düzenlemeler gerçekleştirildi. Çalışmada, Azerbaycan'da bağımsızlığın ilk yıllarından günümüze kadar gerçekleşen devletin yönetsel ve hukuki yapılandırılması sürecine bakllarak, devlet yapısı ve siyasal sistemi genelinde anayasal sistemi, siyasal partileri, yasama ve yürütme kurumları, kamu personel rejimi ele alınarak incelenmiştir. Çalışmada kamu yönetimi sistemindeki mevcut sorunlar analiz edilmekle bu sorunların çözüm yollarına değinılmekte ve bunun ülkenin modern gelişme düzeyine etkileri değerlendirilmektedir. 


\section{GIRISS}

Ortadoğu ve Ön Asya'nın ortasında, Büyük Kafkas dağlarının güneydoğusundaki topraklarda kurulmuş olan Azerbaycan Cumhuriyeti XX. yüzyılın sonunda topraklarının bir bölümünde bağımsızlığına yeniden kavuşmuştur. Yüzölçümü 86.660 km² olan Azerbaycan Cumhuriyeti'nin sınırları 3.660 km'dir. Komşu ülkeleri kuzeyde Dağıstan Özerk Cumhuriyeti (Rusya), kuzeybatıda Gürcistan, güneyde İran, güneybatıda Ermenistan ve Türkiye'dir Ülkenin doğusunda ise, Hazar Denizi bulunmaktadır. Türkiye ile doğrudan sınırı Nahcivan Özerk Bölgesi'nde yer alan 12 km'lik alandır.

Ermenistan tarafından Rus ordusunun desteği ile topraklarının \% 20'si işgal edilmiş, 1 milyondan fazla kişi kendi topraklarından göçe zorlanmış ve mülteci durumuna düşmüştür. Resmi dili Azerbaycan Türkçesi'dir. Para birimi Manatı'dır. 2020 yılı verilerine göre Azerbaycan'ın nüfusu 10,1 milyondur. Ülke nüfusunun \% 71,9'unu 15-64 yaş, \% 5,8'ini 65 yaş üzeri, \%22,3'lük bölümünü de 15 yaş altı oluşturmaktadır. Yıllık nüfus artış hızı $\% 1,2$, ortalama ömür 75 yıldır. 2020 yılı rakamlarına göre nüfusun \%52'i şehirlerde yaşamaktadır.

Azerbaycan, başta petrol ve doğalgaz olmak üzere doğal kaynaklar bakımından da oldukça zengin bir ülkedir. Ülkede 2019 y1lı verilerine göre kişi başına düşen GSYH 8.247,0 Manat'tır (https://www.stat.gov.az/ Erişim Tarihi: 27.04.2020).

Yukarıda belirtildiği gibi 1991 yılında bağımsızlığını yeniden kazandıktan sonra Azerbaycan Cumhuriyeti’nde devletin temel esasları demokratik, laik, üniter bir hukuk devleti şeklinde belirlenmiş ve devlet yönetim sisteminde önemli değişiklikler başlatılmıştır. Bu süreçte, etkili ve verimli çalışan bir idari sisteminin tesis edilmesi ve geliştirilmesi amaciyla önemli değişim ve dönüşümler gerçekleştirilmiş; devletin siyasi, hukuki, ekonomik, sosyal ve ideoloji fonksiyonlarının belirlenmesi ve geliştirilmesi noktasında çalışmalar yürütülmüştür.

Eski rejimden kalan birçok kurum lağvedilmiş, çağdaş idari sistemine ayak uydurabilecek yeni teşkilat yapılanmaları oluşturulmuş, daha etkin bir yönetim sisteminin oluşturulması amacına yönelik olarak pek çok mevzuat düzenlemeleri gerçekleştirilmiştir. Bu düzenlemelerden en önemlisi ise Azerbaycan Cumhuriyeti Anayasasının kabulü olmuştur.

Devlet yönetim sisteminde köklü reformların gerçekleştirilmesi yeni ekonomik ilişkilerin biçimlenmesi açısından zorunluluk arz ediyordu. Bu nedenle, Azerbaycan Cumhurbaşkanı'nın 29 Aralık 1998'de imzaladığı fermanla, Azerbaycan Cumhuriyeti'nin teşkilat yapısında reformların hayata geçirilmesi amacıyla Devlet Komisyonu oluşturulması yoluna gidilmiştir. Fermanda, demokratikleşme ve piyasa ekonomisi alanında hayata geçirilecek reformların devlet yönetiminin etkinliğini ve verimliliğini artırması, ekonominin geliştirilmesi ve kalkınmanın gerçekleştirilmesi için uluslararası standartları karşılayacak mevzuat altyapısının oluşturulması vurgulanmıştır. $\mathrm{Bu}$ fermanın imzalanmasından sonra yapılan reformlarla ihtiyaca cevap veremediği düşünülen devlet kurumları ve bakanlıklar tasfiye edilmiş ${ }^{1}$, merkezi yönetim kurumları yeniden oluşturularak görev ve yetkileri belirlenmiş ve devlet memurlarını konu alan "Devlet Gulluğu Hakkında Kanun" yürürlüğe girmiştir.

Bu çalışmamızda tarihsel gelişim sürecinde Azerbaycan'da devlet yapılanmasına kısaca değinerek 1991 yılında yeniden bağımsızlığını kazanan Azerbaycan Cumhuriyetinin devlet yapısı ve siyasal sistemi genelinde anayasal sistemi, siyasal partileri, yasama ve yürütme kurumları, kamu personel rejimi ele alınarak incelenmiş, ülkenin gelişim düzeyi hakkında değerlendirmelere yer verilmiştir.

\section{AZERBAYCAN CUMHURIYYETI'NIN TARIHSEL GELISŞIMI}

Azerbaycan'da ilk devlet kurumları milattan önce IV. bin yılın sonu III. bin yılın başlarından itibaren Urmiya etrafında kurulmuştur. İlk kurulan Azerbaycan devletleri bölgenin askeri-siyasi tarihinin şekillenmesinde büyük bir etkiye sahip olmuşlardır (Mahmudov, 2007:1). Özellikle Azerbaycan-Türk kavim birliği olan Gutiler ve Lullubiler sadece Azerbaycan'ın değil eski doğu devletçiliğinin gelişmesinde önemli roller üstlenmişlerdir. Bu kavimler o zamanın meşhur Şumer, Akkad ve Aşşur devletlerinin devlet yönetimi geleneğinden faydalanmışlar ve eski Azerbaycan devlet yönetimi kültürünün de yayılmasında etkili olmuşlardır. Gutiler'de sski doğu devlet geleneğinden farklı olarak hükümdarların seçimle iktidara gelmesi geleneği uygulanmaktaydı (Mahmudov,

1 1998'den itibaren Azerbaycan Cumhurbaşkanı Haydar Aliyev, devlet yönetim sisteminin yeni bir yapılandırmaya kavuştuurlması ve merkezi yönetimde çeşitli refromların yapılması amacıyla 31 ferman ve 20'den fazla kanun hükmünde kararname yayımlamıştır. Sadece 2001 yılında yapılan değişiklerle 21 bakanlık ve kamu kurumu lağvedilmiş, 7 bakanlık ve kamu kurumu kuurlmuştur. 
2007:2). Yani yönetim soy-nesep (babadan oğula) yolu ile geçmiyordu. Bu durum, seçim sisteminin doğu devletlerinde batıdakinden daha önce uygulandığının bir kanıtı niteliğindedir.

Süreç içerisinde Azerbaycan'da devlet yönetim kültürü daha da gelişmiş ve ülke topraklarında yeni devletler tarih sahnesine çıkmışlardır. Milattan önce I. Bin yıllıkta-milattan sonra I. Bin yılın başlarında Azerbaycan topraklarında Manna, İskit (Skit, Skif) şahlığı, Midya, Atropatena ve Albanya gibi devletler kurulmuştur. Söz konusu devletler bir yandan Azerbaycan devlet yönetimi kültürünün gelişmesine katkıda bulunurken diğer yanda, ülkenin etnik-siyasi ve ekonomik-kültürel tarihinde ve tek millet olma sürecinde önemli etkilere sahip olmuşlardır (Mahmudov, 2003:64).

Yakın ve orta doğuda tarihin akışının değişmesine sebep olan ve insanlık tarihinde iz bırakan çok karışık askerisiyasi olayların meydana gelmesine, başta komşu devletleri olmak üzere birçok devletin zengin doğal kaynaklara ve askeri-strateji bakımdan büyük öneme sahip Azerbaycan topraklarını ele geçirme konusunda gizli veya açık siyasetlerine rağmen Azerbaycan'da devlet yönetimi günden güne daha da güçlenmiş ve gelişmesini sürdürmüş̧ür. Bu bağlamda, ne Ehemeni-İran İmparatorluğunun uzun süren işgal döneminde ne de çok geniş coğrafyalarda etkisi hissedilen Makedonyalı İskender'in en güçlü olduğu dönemlerde Azerbaycan'ın eski devlet yönetimi kültürünü ortadan kaldırmaya muktedir olunabilmiştir. Ancak, Azerbaycan tarihinin en ağır dönemlerinden biri ile milattan sonra I. bin yılın başlarında karşılaşıldı̆̆ 1 anlaşılmaktadır: III. yüzyılda Azerbaycan'1 Sasani-İ́ran İmparatorluğu, VII. yüzyılda ise Arap hilafeti işgal etmişti. Şüphesiz, bu işgalci devletlerin yönetim gelenekleri Azerbaycan devlet yönetimi üzerinde önemli etkilere sahip olmuştur. Özellikle İslam devlet sistemi ve yönetim ilkelerinin Azerbaycan devlet yönetimi üzerindeki etkisi ön plana çıkmış ve XIX. yüzyılda Rusya'nın Azerbaycan'ı işgaline kadar etkisini sürdürdüğü anlaşılmaktadır (İsmailov, 2013:2528).

Azerbaycan'da IX-XI. yüzyıllarda Saciler, Sulariler, Şirvanşahlar, Şeddadiler, Revvadiler ve Atabeyler gibi feodal devletler kurulmuştur. Moğollar XIII. yüzyılın 20. yıllarında Azerbaycan'ı işgal etmişler ve Hülaküler devletini kurmuşlardır (Azerbaycan Tarihi, 1999:21). XV. yüzyılın başlarında ülkede bulunan feodaller arasındaki ülke dâhilinde savaşların artması Hülaküler devletinin sonunu hazırlamış ve bu devlet yıkılmıştır. Daha sonra XVIII. yüzyılda Azerbaycan'ın Rusya tarafından işgal edilmesine kadar Türkler tarafından Karakoyunlu, Akkoyunlu ve Safevi devletleri kurulmuştur.

Azerbaycan'ın güney bölgelerini kapsayan, Karakoyunlu ve Akkoyunlu Devletleri’nin Başkenti Tebriz'di ve bu devletler sultan ve onun yakınındaki kişiler tarafından idare edilmekteydi. Her iki devletin yönetiminde hükümdara dışında söz sahibi olan, göç etmiş tayfaların oluşturduğu yüksek rütbeli ordu mensupları (emirler), yerli feodal beyler (melikler); âli Müslüman ruhaniler, ulemalar, vakıf yöneticileri, şeyhler ve yönetimde çeşitli görevlerde bulunan üst düzey memurlar olmak üzere dört önemli grup vardı. (Ekberov, 2009:152-153). Her iki devlet iç savaşları önleyememeleri nedeniyle yıkılmışlardır.

Akkoyunlu ve Karakoyunlu devletlerinden sonra Azerbaycan'da kurulmuş olan ve Azerbaycan tarihinde önemli yere sahip olan Safevi Devleti önceki devletlerin geleneklerinden yararlanmış ve o gelenekleri devam ettirmiştir. Safeviler, Azerbaycan'da daha önce kurulmuş olan devletlerden farklı olarak parçalanmış tüm feodal beylikleri tek çatı altında toplayarak güçlü bir merkezi devlet kurmuşlardır. Safevi Devleti'nin kurulmasıyla (1501-1736) ülkede ekonomik hayat canlanmış, zanaat ve ticaret gelişmiş ve şehirler büyümüştür. Ayrıca Safevi Devleti Azerbaycan Türkçesinin devlet dili olarak kullanılmaya başlamasına önemli ölçüde katkı sağlamıştır.

Devletin ilk kurulduğu dönemlerde nispeten daha basit yapıya sahip Azerbaycan bürokratik sistemi zamanla daha karmaşık bir yapıya bürünmüştür. Devlet Şurası Devletin başındaki şahın yanında bulunan nüfuzlu Azerbaycan Türk kavimlerinin önde gelenlerinden oluşturulmuştur. 12 kişiden oluşan bu şuranın temel görevi devletle işleriyle ilgili önemli kararların alınmasında şaha danışmanlık ve rehberlik yapmaktı (Azerbaycan Tarihi, 1999:182-206). Safeviler dönemlinde Azerbaycan, vilayetlere bölünmüştü ve bu vilayetleri şahın atadığ 1 valiler (beylerbeyi) yönetmekteydi. Vali olarak seçilecek kişilerin Azerbaycan Türklerinden olmasına özellikle dikkat ediliyordu. İç işlerinde geniş özerkliğe sahip olan vilayetlerde bulunan valiler halktan topladıkları vergileri hazineye göndermek ve ordu bulundurmak gibi zorunlulukları vardı.

Safeviler, Osmanlı Devleti ile girdiği savaş sonucu zayıflamış ve dağılmıştır. Bundan sonra Azerbaycan XVIII. yüzyıla girerken hanlıklar denen küçük feodal devletlere parçalanmıştır. Bu hanlıklarda devleti yönetenler yasama, yürütme ve yargı yetkilerini ellerinde bulunduran, sınırsız yetkilerle donatılmış hanlardı. Ancak, bu hanlıklarında hana danışmanlık yapan ve üyeleri han tarafından belirlenen divani-şura (devlet şurası) görev yapmaktaydı. $\mathrm{Bu}$ şurada devleti ilgilendiren savaş, barış, vergilerin taksimi, ağır suç işleyenlere cezaların verilmesi gibi en önemli konular tartışılmakta ve karara bağlanmaktaydı. 
Azerbaycan hanlıkları idari taksimat bakımından mahallara ve köylere ayrılmaktaydı. Örneğin, Karabă̆ hanlığında 21, Revan ve Urmiya hanlıklarında 14, Nahcivan Hanlığında 5 mahal mevcuttu. Vali olarak adlandırılan naipler han tarafından atanmakta ve Mahalları yönetmekteydi. Kendhuda ise köyleri yöneten memurlardi.

XVIII. yüzyılda Azerbaycan'ı işgal etmeye çalışan yabancılar için ülkede bulunan küçük devletlerin (hanlıklar) tek bir çatı altında toplanamamaları bir fırsat oluşturmuştur. Bu firsat XVIII. yüzyılın sonu ve XIX. yüzyılın başlarında Azerbaycan'ın güneyini işgal eden İran ve kuzeyini işgal eden Rusya tarafindan kullanılmış ve ülke işgal edilmiştir. Azerbaycan'da devlet yönetim tarihinde XIX. yüzyılın başlarında, (Rusya'nın işgalinden sonra) yeni bir dönem başlamıştır. Bu dönemde işgal olunan hanlıklar ilk başlarda kendi hanlık yönetim sistemlerini devam ettirebilmişler ancak zamanla Rus komutanları tarafından yönetilme olarak nitelendirilen komendant (kumandan) yönetim sistemine geçmişlerdir. Bu değişimden itibaren Azerbaycan'da milli devlet yönetiminin sona erdiği görülmektedir.

Komendant yönetim sisteminde, işgal olunan vilayetlerin başına vilayetin tüm yönetiminden sorumlu olarak Kafkasya'daki Rus ordusunun üst düzey bir subayı komendant olarak atanmaktaydı. Bunlara Kafkasya'nın baş komendantı başkanlık etmekteydi. Komendantların en önemli görevleri arasında devlet malının korunması, mahkemelerin ve polisin işlerine başkanlık edilmesi ve yerli feodallerin Çarizme (Rus Çar'ına) hizmet etme derecelerini denetlemekti (Azerbaycan Tarihi, 2000:94-95). İşgalin gerçekleşmesinden sonra yeraltı ve yerüstü kaynaklar dâhil olmak üzere tüm topraklar, Rus devletinin mülkü sayılmıştır. Yerli feodaller ise sadece Çar'a bağl1lık ve hizmetleri karşılığında toprak ve bazı imtiyazlar alabilmişlerdir.

Rusya'da Ekim 1917 yılında gerçekleşen devrimden sonra 31 ekimde Bakü'de hakimiyetin Sovyetlerin eline geçtiği ilan edildi. Ancak bu devirde Azerbaycan'da Bakü Halk Komissarları Şurası kurulmuş olsa bile henüz Sovyet hâkimiyeti kurulmamıştı. Bu şuranın ömrü uzun sürmedi ve 31 Temmuz 1918 y1lında görevine son verildi.

28 Mayıs 1918 yılında Azerbaycan Milli Şurası Mehmet Emin Resulzadenin başkanlığında doğuda ve Türk dünyasında bağımsız ve demokratik parlamenter sistemle yönetilen ilk Türk cumhuriyetini kurdu (Ülkü, 2000:44). Demokratik ilkelerle yönetilmeyi amaç edinen Azerbaycan Halk Cumhuriyet birçok gelişmiş Batılı devletlerden önce kadınlara seçimlerde oy kullanma ve seçilme hak ve özgürlüğünü tanıdı. 1919 yılında Azerbaycan'da 89 farklı gazete ve derginin yayınlanması devletin basın özgürlüğüne, demokrasiye verdiğgi önemin göstergesiydi. Bu dönemde ülkede siyasal ve ekonomik istikrarsızlık hükümeti etkisiz kılsa da Azerbaycan Halk Cumhuriyetinin Hükümet kabineleri önemli işler görebilmiş, devletin yönetimi için gerekli merkezi ve yerel yönetim kurumları oluşturulmuştur. Ama kamu personel yönetimi ve yerel yönetimlerle ilgili yasal düzenlemelerin ne yazık ki, yapılamamış olmasından dolayı merkezi ve yerel kurumlar eski yasalarla yönetiliyordu.

Azerbaycan Halk Cumhuriyetinin mevcut olduğu yıllarda 5 nazirler kabinesi (bakanlar kurulu) faaliyette bulunmuş, bu kabinelerin üçüne Feteli Han Hoyski ${ }^{2}$, diğer ikisine de Nesib bey Usubbeyov ${ }^{3}$ başkanlık etmiştir (Demirov, 1998:75; Demirli, 2018:246-247). Aynı zamanda Azerbaycan Halk Cumhuriyetinin mevcut olduğu 23 ay gibi kısa bir dönemde (28 Mayıs 1918 - 28 Nisan 1920) milli parlamentonun oluşturulması ve o dönem için demokratik ilkeler esas alınarak parlamento seçimlerinin yapılmasıyla ilgili yasanın kabul edilmesi Azerbaycan tarihinde parlamentarizmin oluşması ve gelişmesi için önemli bir adım sayılabilir. Yasaya göre mecliste 120 milletvekilinin bulunması gerekirdi ve devlet memurluğu bulunanların milletvekili seçildikleri takdirde görevlerinden birini tercih etmek zorunluluğu vardı. 7 Aralık 1918'de Azerbaycan Demokratik Cumhuriyetinin ilk Parlamentosu Bakü'de faaliyete başladı. 1919 yılının sonunda Azerbaycan Parlamentosunda 11 grubun 98 milletvekili vardı. Meclis öz faaliyetini içtüzük esasında teşkil ediyordu. Parlamentonun faaliyeti döneminde 140'a kadar oturumu olmuş, 315 kanun tasarıs1 görüşülmüş, bunlardan çok az tasarı (10-12 civarında) kabul edilmemiş, diğerleri ise yasalaşmıştır. Parlamentoda 11 sürekli komisyon faaliyette idi. Bunlar; mali-bütçe, yasama önerileri komisyonu, askeri, tarım, sorgular, işletim ve düzenleme, denetim, yazı işleri ve iş̧̧i konuları üzere komisyonlar ve yanı sıra Millet Meclisine seçimler üzere merkezi komisyon olmuştur. Bu komisyonlar Hükümetten gelen önerileri ve kendi inisiyatiflerini kullanarak yasa tasarılarını hazırlayıp, genel kurula öneriyorlard1. 28 Nisan 1920 y1lı tarihinde 11. Kızıl Ordu Anadolu Türklerine yardıma gitmek için yol isteme bahanesi ile ülkeye müdahale etti. Azerbaycan Parlamentosu uzun tartı̧̧malardan sonra siyasal iktidarın Azerbaycan komünistlerine verilmesi hakkında karar kabul etti (Aslanov, 2007:117). Sadece 23 ay yaşayabilen bu Cumhuriyet 1920 yılında Ruslar tarafindan devrildi ve Azerbaycan'da yeni bir dönem başladı. Bu

2 I. kabine: 28.05.1918-17.06.1918; II. kabine: 17.06.1918-26.12.1918; III. kabine: 26.12.1918-14.04.1919.

3 IV. kabine: 14.04.1919-22.12.1919; V. kabine: 24.12.1919-30.03.1920. 
Azerbaycan'1 70 yıl egemenliği altında tutan komünist dönemi idi. Azerbaycan Sovyet Sosyalist Cumhuriyeti federe devlet düzeyinde Sovyetler Birliği'nin terkibinde yer aldı ve 19 Mayıs 1921 Anayasası kabul edildi (Rehimli, 2006:51). Genel olarak bakarsak bu Anayasa dışında Sovyetler zamanında Azerbaycan'da 1925, 1927, 1937, 1978 Anayasaları kabul edilmiştir.

Sovyetler Birliğinde devletin örgütlenme ve işleyişi demokratik merkeziyetçilik, komünist partisinin önderliği, halkın yönetime katılması, ulusların eşitliği, sosyalist planlama ve sosyalist hukuksallık olmak üzere altı temel ilkeye dayandırılmaktaydı. Ayrıca, batı devletlerinden farklı olarak Sovyetler Birliği'nin devlet yapısı "kuvvetler ayrılığı" ilkesine dayanmamaktaydı. Sosyalist toplumda yasama, yürütme ve yargı fonksiyonlarını üstlenen devlet organlarının birbirlerini dengeleme ve denetlemelerinin gereksiz olduğu değerlendirilmiştir. Çünkü bu düşüncede uzlaşmaz çelişkileri olan toplumsal sınıfların ortadan kalktığı savunulmaktadır. Buna göre, devletin bu üç gücünün "eşgüdümlü faaliyet ve karşıllkkl etkileşim-işbirliği" türünden bir ilişki içerisinde çalışmalarını yürütmeleri öngörülmüştür (Güler, 1992:17).

Sovyetler Birliği'nde komünist partisi ülkenin yönetilmesinde öncülük ederek devletin tüm sahalarına nüfuz etmekteydi. Partinin Sovyet devleti ve toplumunun tamamını kapsayan "öncü-örgütleyici güç" olma özelliği, Sovyet devlet örgütlenmesinde parti devlet ilişkilerinin ön plana çıkmasına neden olmuştur. Nitekim Sovyet Sosyalist Cumhuriyetleri Birliğinin 1977 Anayasası'nın 6. maddesinde; "Sovyet toplumunun yönetim ve yol göstericisi onun siyasi sisteminin ve sosyal kurumlarının özeği Sovyetler Birliği Komünist Partisidir", denilmekteydi. Başka bir deyişle, devlette mutlak merkeziyetçiliğin hâkim olduğu bir yapılanma söz konusudur. 1980'li yılların başında toplumun demokratikleşmesini amaçlayan perestroyka (yeniden kurma) ideolojisi ortaya çıkmıştır. Bu ideoloji parti destekli Sovyetler Birliği yönetim sisteminin 1991 yılında dağılmasına neden oldu. Buna göre, 1989 yılında seçkilerden sonra halk temsilcileri Sovyetler Birliği Anayasasının 6. maddesini iptal etmişler ve parti hegemonyasındaki yönetim sisteminin ortadan kaldırılmasını gerçekleştirmişlerdir.

\section{AZERBAYCAN DEVLETI SIYYASAL YAPISI}

Azerbaycan siyasal yapısı içerisinde yasama ve yürütme organları ele alınacaktır. Ülkenin anayasal yapısı ve bu yapı içerisindeki siyasal partilere değinilecektir.

\subsection{Anayasal Sistem}

1980'li yılların sonlarında Sovyetler Birliği'nin otoriteyi kaybetmeye başlaması ve arkasından Sovyet Birliği'nin dağılması Doğu Avrupa ülkeleri ve Sovyet Cumhuriyetlerinin demokratikleşme sürecine girmelerine sebep olmuştur. Aslında bu, otoriter bir rejimden liberal demokratik sisteme geçişin bazı örnekleri olmasına rağmen, sosyalist bir devletin herhangi bir savaşta yenilmeden liberal demokrasiye geçme çabasıyla ilk kez karşılaşılması bakımından tarihte daha önce görülmemiş bir süreçti. $\mathrm{Bu}$ nedenle, Sovyetler Birliği'nin etkisindeki Doğu Avrupa ülkeleri ve eski Sovyet Cumhuriyetlerinde siyasi istikrar ve demokrasinin nasıl yaşatılabileceği sorunu çözüm bekleyen en önemli sorundu (Abdullayev, 2001:109).

Sovyetler Birliğinin dağılmasıyla 18 Ekim 1991'de bağımsızlığını yeniden kazanan Azerbaycan Cumhuriyeti, bağımsızlığını kazanmasından sonra demokratikleşme amacını gerçekleştirmek için önemli teşebbüslerde bulunmuştur. Bu teşebbüslerden ilki yeni Azerbaycan Anayasası'nın yapılması olmuştur. Çünkü bir ülkede demokratik bir sistemi kurma ve demokratik kurumları tesis etme yolunda en önemli adım işlevsel bir anayasanın hazırlanmasıdır. Daha kapsamlı bir ifadeyle, bir ulusun geçmişle uzun bir süre boyunca açık bir biçimde kopup yeni bir başlangıç yapmak zorunda kaldığı zamanda yeni bir anayasa son derece gerekli olmaktadır. Genel olarak kabul edilen bu ihtiyacın bir zamanlar demir perde ülkelerinin gerisinde olan sosyalist devletten demokratik devlet sistemine ve liberal ekonomiye geçmekte olan ülkeler kadar açık bir örneği yoktur (Abdullayev, 1998:15).

Azerbaycan Anayasasının hazırlanmasına 1991 yılında başlanmış ve 12 Kasım 1995 yılında yapılan ve seçmenlerin \%86'sının iştirak ederek oy kullananların \%91,9'unun Anayasanın kabul edilmesi yönünde oy kullandığı bir referandum ile kabul edilmiştir (Azerbaycan Gazetesi, 10 Kasım 1996). Ülkedeki siyasi istikrarsızlık nedeniyle Anayasanın hazırlanmasına 1991'de başlanmasına rağmen oldukça uzun sürede bir süre sonra referandum gerçekleştirilebilmiştir. Yürürlüğe girişi 27 Kasım 1995'te gerçekleştirilebilen Azerbaycan Anayasası Devlet Başkanı Haydar Aliyev'in başkanlığında uzmanlar kurulundan oluşan bir "Anayasa Komisyonu" tarafından hazırlanmıştır (Azerbaycan Gazetesi, 11 Kasım 1995). Anayasa Komisyonu altı ay süreyle faaliyette bulunmuştur.

Anayasa'nın hazırlanmasında 1991 yılında kabul edilen Bağımsızlık Beyannamesinden esinlenilmiştir. Bu 
nedenle, anayasayı pozitif yönden karakterize eden esas öğeler, devlet otoritesini Sovyet rejiminin sınırsız merkezîleştirilmesinin aksine yasama, yürütme ve yargı erklerine bölmesi; insan hak ve özgürlüklerine geniş yer vermesi ve yerel yönetim anlayışının benimsenmiş olmasıdır.

Anayasanın "Genel Esaslar" başlı̆̆ı taşıyan birinci bölümün ilk maddesinde; "Azerbaycan Devletinde egemenliğin tek kaynă̆ szerbaycan halkıdır" denilmek suretiyle Azerbaycan'ın bir Cumhuriyet olduğu belirtilmiştir. 7. maddede ise devletin esasları belirtilmiştir. Bu maddenin I. fikrasında Azerbaycan Devleti; demokratik, hukuk kuralları ile yönetilen, laik ve üniter bir Cumhuriyettir ibaresi yer almaktadır. Aynı maddenin III. fikrasında ise "Azerbaycan Cumhuriyetinde devlet egemenliği kuvvetler ayrlliğl prensibine dayanır", denilmektedir. Bu hükme göre;

- Yasama yetkisini Azerbaycan Cumhuriyeti Milli Meclisi kullanır.

- Yürütme yetkisi Azerbaycan Cumhuriyeti Cumhurbaşkanı'na aittir.

- Yargı yetkisini Azerbaycan Cumhuriyeti Mahkemeleri yerine getirir.

Azerbaycan Cumhuriyeti üniter devlet yapısına sahip olmasına rağmen Anayasanın 134. maddesine göre bünyesinde Nahcivan Özerk Cumhuriyeti bulunmaktadır. Nahcivan Özerk Cumhuriyeti, Azerbaycan Cumhuriyetine bağl1 özerk devlettir.

Genel olarak değerlendirildiğinde eski Sovyet Cumhuriyetlerinin çoğunda olduğu gibi Azerbaycan Anayasasının da bazı yönleriyle başkanlık sisteminin özelliklerini taşıdığı bazı yönleriyle de güçlü yürütme ilkesinden hareket ettiği anlaşılmaktadır. Bunun nedeni, eski Sovyetler Birliği Cumhuriyetlerinin ve tabi ki Azerbaycan'ın uzun zaman tek parti iktidarıyla yönetilmeleri ve parlamenter sistem geleneklere sahip olmamalarıdır. Temel insan hak ve özgürlüklerine geniş yer ayrılan Anayasanın ikinci bölümünde insan ve vatandaş hak ve özgürlüklerinin sağlanmasının "devletin yüksek amacı" olduğu ifade edilmektedir. Anayasada herkese serbest toplanma özgürlüğü verilmiş ve tüm vatandaşlar için toplumun siyasi hayatına ve devletin yönetilmesine katılım hakkı güvence altına alınmıştır. Anayasa da vatandaşlara oldukça geniş sosyal haklar da sağlanmıştır. Buna göre vatandaşlara çalışma hakkı (m.35), grev hakkı (m.36), dinlenme hakkı (m.37), sosyal teminat hakk1 (m.38), eğitim hakkı (m.42), konut hakkı (m.43), gibi geniş sosyal haklar sayılmıştır.

Anayasanın 152. maddesine göre Anayasa metninde değişiklik sadece referandum yoluyla yapılabileceğinden Azerbaycan anayasasının önemli bir özelliği katı anayasa olmasıdır. Ayrıca, anayasanın 155. maddesine göre, 1, $2,6,7,8$ ve 21. maddelerin değiştirilmesi ve 3 . faslın tümünün sınırlandırılması referandum yoluyla dahi mümkün değildir ${ }^{4}$. Ayrıca Anayasada, anayasanın üstünlüğü prensibi oldukça açı bir şekilde kabul edilmiştir. Anayasanın 147. maddesinde "Azerbaycan Cumhuriyeti Anayasası, Azerbaycan Cumhuriyetinde en yüksek hukuki güce sahiptir ve yasama sisteminin temelidir", hükmüne yer verilmektedir. Bu maddenin işlevsel olabilmesi için anayasaya aykırı kanunlar veya işlemleri iptal edebilecek bir mahkeme bulunmalıdır. Anayasa bu durumu göz önüne alarak liberal demokrasiye geçiş aşamasının temel taşlarından olan Anayasa Mahkemesini öngörmüştür.

2002 ve 2009 yıllarında Referandum ile Anayasanın bazı maddelerine değişiklik yapılmıştır. 26 Eylül 2016 yılında yapılan referandum ile Azerbaycan Cumhuriyeti Anayasasının 23 maddesinde değişikliğe gidilerek, 6 yeni madde eklenmiştir. Bu değişikliğin en önemli kısmı ise Azerbaycan Cumhurbaşkanı birinci yardımcısı (First Vice-President) ve Cumhurbaşkanı yardımcıları görevlerinin tahsis edilmesi oldu. Azerbaycan'daki en yüksek ikinci anayasal makam olan Azerbaycan Cumhurbaşkanı birinci yardımcısı ve Cumhurbaşkanı yardımcıları Cumhurbaşkanı tarafından atanır veya görevden alınır (Anayasa md.103-1).

Bir hususun daha belirtilmesinde fayda var ki, bu da Azerbaycan yönetim sisteminde yapılması gereken reformların hem ülkenin mevcut yönetsel yapısına hem de anayasaya uygun olarak yapılmaları zorunluluğudur. Çünkü, Azerbaycan'da başkanlık sistemi benimsemiş ve bu sistemin Batı Avrupa ülkelerine uygun hale getirme çabaları burada büyük ihtimalle yetersiz kalacaktır. Azerbaycan'da zaman zaman hem ekonomik hem de yönetim alanında radikal kararların alınması gerekliliği Başkanlık sisteminin önemi göstermektedir.

4 Anayasanın 1. maddesi: iktidarın kaynă̆ı, 2. maddesi: halkın egemenliği, 6. maddesi: iktidarın seçim dışı yollardan ele geçirilmesinin yasaklanmas1, 7. maddesi: Cumhuriyetin niteliği , 8. maddesi: Azerbaycan Devletinin Başı, 21. maddesi: devletin dili, 3. Fasıl ise temel hak ve özgürlükler başlığı taşımaktadır. 


\subsection{Siyasal Partiler}

Azerbaycan'da siyasal partiler XX. Yüzyılın 80'li yıllarının sonu, 90'lı yılların başlarında oluşmaya başladı. 1988-1993 yıllar arasını partilerin oluşma süreci olarak algılaya biliriz. 90'lı yılların başlarında Sovyet dönemine özgü sosyal oluşumların devamlı olarak dağılmaya başlaması ve topumun siyasi etkinliğinin yükselmesi siyasal partilerin oluşum sürecini hızlandırdı. Bu devirde partilerin oluşum hızı, onların siyasi sürece katılım düzeyi, toplumsal alandaki kaos ve gerilim arasındaki karşılıklı etkileşimin olduğunu söylememiz gerekir. Şöyle ki, demokrasiye geçiş devrini yaşayan toplumlarda siyasal partiler parti kavramının genel ölçütlerine uymadığından onların oluşumunda liberal demokrasinin kökeni ile kıyaslamak mümkün değildir. Toplumsal değişim sürecinde siyasal partilerin kurumsallaşmasının gözlemlenmesi onu gösteriyor ki, demokratik devletin ilk oluşum aşamasında kitlelerin istekleri ile siyasi bilinç ve siyasi kültür arasında ters orantının olması bu süreci olumsuz yönde etkileye bilmektedir (Allahyarova ve Memmedov, 2010:10). Nitekim bunun sonucu olarak Azerbaycan'da bağımsızlık mücadelesinde halk partilerde örgütlenmek yerine Azerbaycan Halk Cephesi adı verilen ve tüm toplumsal kesimleri içine alan bir siyasal kurumda örgütlenmeyi tercih etmiş̧tir. Tabii ki, Azerbaycan'da parti düzeyinde siyasi örgütlenmeni tetikleyen ilk adımlar Sovyetlerin çökmeye başlaması ile Ermenistan'ın Rusya'nın desteği ile Azerbaycan topraklarına tecavüzü ve bu tecavüze karşı halkın direnişi fonunda siyasal birliklerin oluşumunu da eklememiz gerekir.

1991 yılının sonbaharında Karabağa Nicat Cemiyyeti, Azerbaycan İslam Partisi, Vahid Azerbaycan Uğrunda Mübareze İttifakı, Azerbaycan Genç Sosyal Demokratik Teşkilatı, Genç Türkler Teşkilatı, 1992 yılının yazında Azerbaycan Milli İstiklal Partisi, aynı yılın sonbaharında Musavat Partisinin yeniden oluşum kongresi yapılmış, Yeni Azerbaycan Partisi kurulmuş, Bozkurt Partisi faaliyete başlamıştır. 1993 yılının ortalarında Azerbaycan'da 30'aa yakın siyasal parti, siyasal cemiyet ve teşkilat vardı (Azerbaycan Respublikası [1991-2001], 2001:42). 2 Haziran 1992 yılında siyasal partilerin faaliyetini düzenlenmek amacıyla "Siyasi Partiler Hakkında Kanun" kabul edildi. Böylelikle siyasal partilerin oluşumunda önemli bir adım atılmış oldu (Allahyarova ve Memmedov, 2010:11). Kanun'da 1996 yılında ve 2001-2019 yılları arasında muhtelif değişiklikler yapılmıştır.

Günümüzde ülkenin siyasi arenasında 70 civarında siyasal parti mevcuttur. Bu partilerin 56 tanesi devlet tarafindan resmi olarak tescil edilmiştir. Yine bu partilerden 9 tanesi parlamentoda temsil edilmektedir. Bunun dışında Azerbaycan'da 5256 kamu yararına kurum faaliyette bulunmaktadır. 9 Şubat 2020 Parlamento seçimlerinde Yeni Azerbaycan Partisi parlamentoda \%56 oranında milletvekili ile temsil edilmektedir. Milletvekillerinin \%32 ise bağımsızlardan oluşmaktadır. Parlamentoda yer alan \%12'lik kısım ise diğer 8 parti üyelerinden oluşmaktadır. Ama bu partilerin de çoğunluğu iktidar odaklı muhalif partilerdir.

Azerbaycan'da siyasi partilerin rekabet gücü zayıftır. Bu hem partilerin maddi kaynaklarından hem de toplumsal ihtiyaçlara cevap verememesinden kaynaklanmaktadır. Özellikle hiç bir parti iktidar partisi ile rekabet edecek güçte değildir. İktidar partisi de bu durumdan memnundur. Alternatif muhalif partilerin güçlenmesini istememektedir. Azerbaycan'da partiler sayıca fazla olmalarına rağmen, bu partilerin \%90'ı iktidar partisi ile rekabet edebilecek toplumsal tabandan yoksundurlar. $\mathrm{Bu}$ durumu sosyal, siyasal ve yönetsel yapıdan kaynaklanan nedenleri vardır. Azerbaycan'da siyasal oluşumları ve partileri sahip oldukları siyasi düşünce tarzına ve niteliklerine göre genel olarak üç kısma ayrılabilir;

1. Sağ düşünceli, neoliberal, anti-komünist odaklı partiler,

2. Merkezci karaktere sahip demokratik partiler,

3. Sosyalist ideolojideki sol düşünceli partiler.

1993 yılına kadar ıslahatçılarla muhafazakarlar, 1993'den sonra da demokratlar ile radikaller arasında bir siyasal mücadele olmuştur (Allahyarova ve Memmedov, 2010:28). Ama tüm partilerin programlarında belirtilen nihai amaç Azerbaycan'da demokratik yönetim sistemini pekiştirmek, Azerbaycan'ın işgal altında olan topraklarını kurtararak, ülkenin milli birlik ve bütünlüğünü korumaktır.

\subsection{Yasama Organı}

Azerbaycan'ın yasama organı Anayasasının 7. ve 81. maddelerine göre yasama yetkisini kullanan ve 125 milletvekilinden oluşan Milli Meclisi'dir. Milletvekilleri majoritar (temsili) seçim sistemi ile eşit, doğrudan ve gizli oy kullanılarak 5 yıllığına seçilen Milli Meclis seçimleri en son seçimler 9 Şubat 2020'de yapılmıştır. 
Seçimlere katılma hakkına sahip olan ve seçilmesinde herhangi bir yasal engeli bulunmayan Azerbaycan Cumhuriyeti vatandaşları milletvekili adayı olabilirler. İç Tüzük 17 Mayıs 1996'da Cumhurbaşkanı tarafından onaylanmıştır. Bu iç tüzüğe göre Milli Meclis faaliyetini açıklık, çok partililik, siyasi çoğulculuk ve istenilen konunun serbest şekilde görüşülmesi ilkelerine uygun olarak daimi komiteler ve komisyonlar marifetiyle yürütür. Milli Meclis, ilki ilkbahar dönemi (1 Mart-31 Mayıs) ve ikincisi son bahar dönemi (30 Eylül - 30 Aralık) olmak üzere yılda iki dönem toplanır. Zaman zaman olağanüstü de toplanabilen Milli Meclisi olağanüstü toplantıya çağırma yetkisi Milli Meclis Başkanı, Cumhurbaşkanı ve 42 milletvekiline verilmiştir. Toplantı yeter sayısı 83 milletvekili olan Milli Meclis yetkileri dâhilinde kanunlar ve kararlar çıkarır, kendi çalışma programını belirler, başkanlık divanını ve mali denetim birimini (Sayıştayı) oluşturur.

Anayasanın 95. maddesine göre Milli Meclisin yetkileri; Azerbaycan Cumhuriyeti Milli Meclisinin yönetimi, Devlet Başkanının düzenleyici işlemleri ile Azerbaycan Cumhuriyeti diplomatik temsilciliklerinin kurulması, devletlerarası antlaşmalar onaylamak ve anlaşmaları feshetmek, devlet başkanının onayı ile ombudsman seçmek, devlet bütçesini onaylanmak ve bütçenin yürütülmesi aşamasını denetlenmesi, devlet başkanının talebiyle savaş ilan edilmesi ve barış imzalanmasını onaylamak, anayasada belirlenmiş bazı durumlarda devlet başkanının fermanlarını onaylamak, Azerbaycan Cumhuriyeti Bakanlar Kuruluna güven oyu vermek, Azerbaycan Cumhuriyeti askeri doktrinasını onaylamak, başbakanın atanmasını onaylamak, devlet başkanının yazılı beyanatı ile Anayasa Mahkemesi, Yüce Mahkeme ve Uyuşmazlık Mahkemesi yargıçlarını atamak, Anayasa Mahkemesinin yazılı talebi ile Devlet Başkanını görevden uzaklaştırmak, devlet başkanının onayı ile Azerbaycan Cumhuriyeti Başsavcısını atamak ve görevine son verilmesini onaylamak, devlet başkanının onayı ile Azerbaycan Cumhuriyeti Milli Bankasının yönetim kurul üyelerini atamak ve görevlerine son vermek, belediyelerin yıllık faaliyetinin değerlendirmek, referandum yapılmasına ve affetme işlemlerine ilişkin karar vermek olarak karşımıza çıkar.

Azerbaycan Cumhuriyetinin Milli Meclisine kanun tasarısı sunma yetkisi, milletvekillerine, Cumhurbaşkanına, Azerbaycan Cumhuriyeti Yüce Mahkemesine, Azerbaycan Cumhuriyeti Başsavcısına ve Nahçıvan Özerk Cumhuriyetinin Yüce Meclisine aittir. Aynı zamanda Azerbaycan Cumhuriyetinin seçme hakkı olan 40 bin vatandaşına her hangi bir konu hakkında toplu imza ile Azerbaycan Cumhuriyetinin Milli Meclisine kanun tasarısı sunma yetkisi tanınmıştır. Anayasanın 96. maddenin 6. fikrasında 40 bin vatandaşın bu hakkı ne zaman ve nasıl kullanacağı konusunun, daha doğrusu bu hakkın kullanılma kurallarının yasalarla düzenleneceği belirtilmiştir.

\subsection{Yürütme Organı}

Azerbaycan'da devlet başkanı yürütme organının başıdır. Yürütme organı teşkilat yapısı itibariyle Cumhurbaşkanının başkanlık ettiği merkezi idare teşkilatı (devlet), merkezi idarenin başkent dışında örgütlenmiş taşra birimleri ve yerel yönetimlerden (belediyeler) oluşmaktadır.

\subsubsection{Devlet Başkanı}

Yukarıda da belirttiğimiz gibi, 18 Ekim 1991 yılında kabul edilmiş Azerbaycan Cumhuriyeti Bağımsılık Beyannamesinin 13. maddesinin 3. fikrasına göre: "Yüce yürütme yetkisi Azerbaycan Cumhurbaşkanı'na (Prezidenti'ne) mahsustur". Bağımsızlığın resmen ilanından önce 18 Mayıs 1990 yılında Azerbaycan Sovyet Sosialist Respublikasının Âli (Yüce) Sovyetinin kararı ile Azerbaycan SSR Prezidenti (Cumhurbaşkanı) görevi tahsis edildi. 1991 yılında bağımsızlığına kavuşan Azerbaycan Cumhuriyetinde seçimle Cumhurbaşkanı görevinde bulunanlar, Azerbaycan Komunist Partisi eski Genel Başkanı sonradan bağımsız olarak seçilen Ayaz Mutallibov (1991-1992), Azerbaycan Milli Bağımsızlık mücadelesinin lideri ve Azerbaycan Halk Cephesinin Genel Başkanı Ebulfez Elçibey (1992-1993), Azerbaycan halkının ümummilli lideri, Yeni Azerbaycan Partisi Genel Başkanı Haydar Aliyev (1993-2003), Yeni Azerbaycan Partisi Genel Başkanı İlham Aliyev (2003-bu güne kadar) .

1995 yılında kabul edilen, devleti hukuka bağlayan ve devletin en önemli varlık nedenlerinden biri olan Azerbaycan Anayasasının 7. 8. ve 99. maddelerine göre, Cumhurbaşkanı hem Devlet Başkanı hem de yürütme organının başıdır. Başka bir deyişle Azerbaycan, Anayasasının belirlediği kurallar uyarınca güçlü bir başkanlık sistemiyle yönetilir. Görev süresi 7 yıl olan Başkan halk tarafından doğrudan genel seçimle seçilir, Azerbaycan Anayasasının 100. maddesine göre, Azerbaycan'da10 y1ldan fazla sürekli yaşayan, mahkûmiyeti bulunmayan, oy kullanma hakkına sahip olan, yüksek okul mezunu, çifte vatandaşlığı olmayan Azerbaycan Cumhuriyeti vatandaşları Cumhurbaşkanı seçilme yeterliliklerine sahiptir. Seçmenlerin en az \%25'inin seçimlere katılması ve oy kullanması durumunda seçim yapılmış sayılmakta ve seçimlere katılan seçmenlerin salt çoğunluğunun 
$(\% 50+1)$ oyunu alan aday Cumhurbaşkanı seçilir. İlk turda bu oya ulaşılamaması durumunda ilk turda en fazla oy almış iki aday arasında ikinci tur seçimi düzenlenmektedir. İkinci turda en fazla oy alan aday Cumhurbaşkanı seçilir. Anayasaya göre 14 gün içinde Anayasa Mahkemesi, Cumhurbaşkanı seçim sonuçlarını resmen ilan eder. Bundan sonra 3 gün içinde Cumhurbaşkanı yemin ederek resmen göreve başlar.

Azerbaycan Cumhurbaşkanının hem devletin hem yürütmenin başı olarak ikili statüden kaynaklanan yetkileri söz konusudur (Anayasa 109. m). Bu maddede, ülke dâhilinde devletin yüce temsilcisi gibi Cumhurbaşkanının yasama, yürütme, yargı ve dış ülkelerle ilişkilerde yetkileri sayılmıştır. Cumhurbaşkanı aynı zamanda Milli Meclisin onayı ile savaş ve barış ilan etmeye yetkili olup, başkumandan gibi savunma ve güvenlik alanında ülkenin iç ve dış güvenliğinin sağlanmasından sorumludur. Cumhurbaşkanı'nın yasama ile ilgili yetkileri;

"Milletvekili seçimlerinin yapılma zamanını belirtmek, Milli Meclise kanun tasarısı sunmak, kanunları imzalayıp yayınlamak, veto hukukunu kullanmak, Anayasa mahkemesi, Yargıtay ve Uyuşmazlık mahkemelerine hakem adaylarını atanmaları için Milli Meclise sunmak, baş savcının adaylığını Milli Meclise sunmak, Milli Meclisin onayı ile Başbakanı atamak, Azerbaycan Cumhuriyeti Milli Bankası Yönetim Kurulu üyelerinin göreve atanmaları ve görevden azledilmeleri için Milli Meclise yazılı beyanat göndermek, Azerbaycan Cumhuriyeti Askeri Doktrinini Milli Meclisin onayına sunmaktır".

26 Eylül 2016 tarihinde yapılan Anayasa değişikliği ile Cumhurbaşkanı'na bazı şartların oluşması durumunda Meclisi feshetme yetkisi verilmiştir (Azerbaycan Cumhuriyeti Anayasası, md.98). Cumhurbaşkanının hükümetin faaliyeti ile ilgili yetkileri;

"Milli Meclisin onayı ile Başbakanı atamak, Bakanlar Kurulu toplantılarına başkanlık etmek, Bakanlarl ve devlet komiteleri başkanların göreve atamak ve azletmek, Bakanlar Kurulunun çalışma kuralların onaylamak, Bakanlar Kurulunun hazırladı̆̆ devlet bütçesini Milli Meclise sunmak, Bakanlar Kurulunun istifası hakkında karar kabul etmektir".

Cumhurbaşkanının dış siyaset, milli güvenlik ve savunma ile ilgili yetkileri;

"Ülkeni içeride ve yurt dışında temsil etmek, yurt dışında görev yapacak Büyükelçileri atamak ve dış ülkelerde diplomatik temsilciliklerin açılması için Milli Meclise yazılı beyanat göndermek, uluslararası antlaşmaları imzalamak, uluslararası antlaşmaları ratifikasiya etmek için Milli Meclise sunmak, başkumandan olarak Milli Meclisin onayı ile olağanüstü hal ve slkıyönetim ilan etmek, ülkenin askeri doktrinini onaylamak, Milli Güvenlik Şurasını oluşturmaktır”.

Milli Güvenlik Şurası 10 Nisan 1997 yılında Cumhurbaşkanının Fermanı ile oluşturulmuştur. Cumhurbaşkanı başkanlığında toplanan Şuranın üyeleri Cumhurbaşkanı yardımcıları, Milli Meclis Başkanı, Başbakan, Cumhurbaşkanlığı Administrasiyası (Cumhurbaşkanlığ̣ Yürütme Kurumu) Başkanı, Dış İlişkiler üzere Devlet Müşaviri, Askeri işler üzere Devlet Müşaviri, Başsavcı, Dış İşleri Bakanı, Savunma Bakanı, İç İşleri Bakanı, Devlet Güvenlik Teşkilatı Başkanı ve Dış İstihbarat Teşkilatı Başkanından oluşmaktadır. Cumhurbaşkanının devlet kurumlarının faaliyetlerinin koordine edilmesi ile ilgili yetkileri;

"Yürütme kurumlarının Anayasaya, kanunlara ve Cumhurbaşkanı fermanlarına aykırı kararlarını iptal etmek, devlet kurumları arasında çıkan uyuşmazlıkları çözmek, insan haklarının, egemenliğin ve ülkenin arazi bütünlügünün korunması için gerekli düzenlemeler yapmak, bazı konuları referanduma sunmak, vatandaşlık konuların halletmek, onursal madalya ve adlar vermektir".

\subsubsection{Merkezi Yönetim Yapısı ve Bakanlar Kurulu}

Azerbaycan Cumhuriyetinde devlet yetkisi, Cumhurbaşkanı ve ona bağlı Cumhurbaşkanlığı Administrasiyası (Cumhurbaşkanlığı Yürütme Kurumu), Cumhurbaşkanı yardımcıları (Vice President), Milli Meclis, hükümet ve mahkemeler tarafından, yasama, yürütme ve yargı güçlerinin ayrılığı ilkesine göre kullanılmaktadır. Merkezi devlet idaresi tek bir tüzel kişiliğe sahipken, âdem-i merkeziyet ilkesi çerçevesinde faaliyet yürüten yerel yönetimlerin devletten farklı tüzel kişilikleri vardır.

Azerbaycan Cumhurbaşkanı merkezi yönetimin başında bulur ve hem Devlet Başkanı hem de yürütmenin başıdır. Anayasanın 105. maddesine göre, Azerbaycan Cumhurbaşkanı zamanından önce görevinden ayrıldıktan 60 gün süresinde yeni Cumhurbaşkanı seçimi yapılır. $\mathrm{Bu}$ sure zarfinda Cumhurbaşkanı yetkilerini Cumhurbaşkanı 1. yardımcısı kullanır. Anayasanın 114. maddesinde belirtildiği üzere, Azerbaycan Cumhuriyeti Cumhurbaşkanı yürütme ile ilgili yetkilerinin kullanılmasına kendisine yardımcı olması amacıyla 
Cumhurbaşkanı yardımcılarını görevlendirir ve Bakanlar Kurulu'nu oluşturur.

Bakanlar Kurulu Cumhurbaşkanı'nın üst düzey yürütme kurumudur ve sadece Cumhurbaşkanı'na karş1 sorumluluğu söz konusudur. Yeni Cumhurbaşkanı'nın seçilmesi durumunda Bakanlar Kurulunun istifa etmesi zorunludur. Anayasanın 116. maddesinde fiili olarak Bakanlar Kurulu'nun yetki süresinin Cumhurbaşkanı'nın yetki süresi kadar olabileceği ifade edilmektedir. Anayasanın 115. maddesine göre ise, Bakanlar Kurulu başbakan, başbakan yardımcıları, bakanlar ve diğer merkezi yürütme kurumları başkanlarından teşekkül etmektedir. Anayasaya göre yürütme kurumlarının sınıflandırmak gerekirse, üst düzey yürütme kurumu, merkezi yürütme kurumları ve yerel yürütme kurumları şeklinde ayrım yapılabilir. Üst düzey yürütme kurumu olarak Bakanlar Kurulu örnek verilebilir. Merkezi yürütme kurumları olarak da bakanlıklar, Bakanlar Kuruluna bağl1 komiteler, devlet komiteleri, hizmetler (örneğin, Baş Devlet Feldyeger hizmeti), Bakanlar Kuruluna bağlı baş idareler (örneğin, Baş Devlet Arşivi ); yerel yürütme kurumları olarak illerde valilikler sayılabilir.

Yukarıda da belirtildiği gibi bakanlar ve devlet komiteleri başkanları ve valiler gibi tüm merkezi yürütme kurumları başkanları doğrudan Cumhurbaşkanı tarafından atanır ve bu atamaları Milli Meclisin onayına sunmaya gerek yoktur. Bakanların ve devlet komiteleri başkanlarının milletvekili olma zorunlulukları yoktur. Başbakan ise, Anayasanın 95. maddesinin 9. fikrasına göre Cumhurbaşkanı tarafından Milli Meclisin onayı esasında atanır. Anayasanın 118. maddesinin 3.fikrasına göre Milli Meclis 3 defa başbakanın atanmasına onay vermezse Cumhurbaşkanı Milli Meclisin onayı olmadan başbakanı direkt olarak atayabilir.

Bakanlar Kurulunun yetkileri Azerbaycan Cumhuriyeti Anayasası'nda belirtilmiştir. Buna göre, Bakanla Kurulu Cumhurbaşkanı'nın kabul ettiği kanun hükmünde kararların ve fermanların uygulanması odaklı çalışmaktadır. Bu kararların gerekli düzeyde uygulanmaması Bakanlar Kurulunun genel olarak sorumlu olmasına sebep olur. Anayasanın 120. maddesine göre, Bakanlar Kurulu bazı konularda kararlar alabilmekte ve kanun hükmünde kararnameler kabul edebilmektedir.

Genel olarak Bakanlar Kurulunun, Devlet bütçesi tasarısını hazırlayıp Cumhurbaşkanına sunmak, devlet bütçesinin uygulanmasını sağlamak, devletin ekonomik ve sosyal politikalarını gerçekleştirmek için gerekli düzenlemeleri yapmak, bakanlıklara ve diğer merkezi yürütme kurumlarına başkanlık etmek, maliye-kredi ve para politikasını gerçekleştirmek ve Cumhurbaşkanının belirlediği çeşitli görevleri yerine getirmektedir.

Azerbaycan'da Harici İşler (Dışişleri), Dahili İşler (İçişleri), Müdafaa (Savunma), Müdafaa Sanayi (Savunma Sanayi), Adliye, Maliye, İktisadiyyat (Ekonomi), Energetika (Enerji), Emek ve Ahalinin Sosyal Savunmas1, Kend Tesrrüfatı (Tarım ve Köy İşleri), Ekologiya ve Tebii Servetler (Ekoloji ve Doğal Kaynaklar), Medeniyyet (Kültür), Tahsil (Eğitim), Sehiyye (Sağl1k), Negliyyat, Rabite ve Yüksek Teknologiyalar (Ulaştırma, İletişim ve Yüksek Teknolojiler), Gencler ve İdman (Gençler ve Spor), Fövgalade Hallar (Olağanüstü Haller), olmak üzere toplam on yedi bakanlık vardır. Bakanlıkların dışında "devlet komiteleri", "devlet komisyonları", "devlet ajansları", "devlet hizmetleri" gibi örgütlenmeler faaliyet göstermektedir. Bakanlıkların başında bakanlar bulunur. Bakanlar, bakanlık teşkilatının en üst amiri konumundadır. Bakanın ardından bakan yardımcıları ve bakanlık yürütme aygıtının başkanı (bakanlık icra aparatının rehberi) gelir. Bunlar, bakanlık teşkilatının genel nitelikteki görevleri içinde belirli özel yetkilerle donatılmıştır. Devletin taşra örgütlenmesinde, illerde bakanlıkların ve diğer merkezi yönetim kurumlarının temsilcileri bulunur ve bunların hepsi valinin (icra başçısının) başkanlığında görevlerini sürdürmektedirler.

\subsubsection{Nahçivan Özerk Cumhuriyeti}

Özerklik, siyasi-hukuki anlamda üniter, bazen federatif bir ülkenin belirli bir kısmında kendi-kendini yönetim biçimi şeklinde tanımlanabilir. Özerklik her şeyden önce ülkenin tüm bölgeleri için söz konusu olmayıp, üniter devletin sadece coğrafi konumu, etnik yapısı ve/veya milli özelliğine göre farklılık taşıyan belli bir kısmına verilir. Hukuk literatüründe özerkliğin iki şekline geniş yer verilmiştir. Bunlardan birincisi geniş anlamda özerliktir ki yasama, yürütme ve yargı yetkisi bulunan özerk cumhuriyetleri ifade ederken, diğeri ise sadece yerel nitelikli bazı hizmetleri yerine getirmede merkezden bağımsız olma durumunu ifade etmede kullanılmaktadır (Onar, 1986:611; Tortop, 1988:11; Keleş, 1994:73).

Özerklik konusu Azerbaycan Anayasa Hukukunda da teorik ve pratik olarak geniş bir şekilde tartışılmıştır. 1995 Azerbaycan Anayasası'nın 134. maddesinde Nahcivan Özerk Cumhuriyetinin hukuki statüsüne yer verilmiştir. Buna göre, Nahcivan Özerk Cumhuriyeti Azerbaycan Cumhuriyetine bağlı özerk bir devlettir. Nahcivan Özerk Cumhuriyeti iç işlerinde kısmen bağımsız ancak dış işlerinde Azerbaycan Cumhuriyetine bağlı olan ve coğrafi olarak Azerbaycan'ın ayrılmaz bir parçasıdır. 29 Aralık 1998'de Azerbaycan Cumhuriyeti Milli Meclisi tarafindan onaylanan Nahcivan Özerk Cumhuriyeti Anayasasının 1. maddesinin 2. fikrasına göre, Nahcivan 
Özerk Cumhuriyetinin statüsünü Azerbaycan Cumhuriyetinin Anayasası ve 16 Mart 1921'de Moskova ve 13 Ekim 1921'de imzalanan Kars uluslararası antlaşmaları belirlemektedir. Atatürk'ün Türk kapısı olarak adlandırdığı Nahcivan bölgesi Türkiye'nin doğu sınırları için oldukça stratejik bir önem taşıyordu. Nahcivan'ın yabancı güçler tarafından işgal edilmesini engelleyen Atatürk Moskova antlaşmasının uygun şartlarla imzalanmasını ve Nahcivan'a Azerbaycan'ın terkibinde özerklik statüsü verilmesini sağlamıştır.

Yukarıda da belirtildiği gibi Nahcivan Özerk Cumhuriyeti hem kendine özgü bir Anayasaya hem de yasama, yürütme ve yargi yetkilerini kullanan kurumlara sahiptir. Yasama görevi Nahcivan Özerk Cumhuriyeti Yüce Meclisi tarafindan, yürütme yetkisi Nahcivan Özerk Cumhuriyeti Bakanlar Kurulu tarafından ve Yarg1 yetkisi de Nahcivan Özerk Cumhuriyeti Mahkemeleri tarafindan kullanılmaktadır.

Yönetim yapıs1 itibariyle parlamenter cumhuriyet olan Nahcivan Özerk Cumhuriyeti Azerbaycan Cumhuriyetinden farklı yönetim sistemine sahiptir. Bu sistemin bir gereği olarak, parlamento tarafindan oluşturulan ve yürütme yetkisini kullanan bakanlar kurulu yine yasama yetkisini kullanan meclise karş1 sorumludur. Merkezi teşkilat yapısına bakıldığında ise, savunma bakanlığı hariç Azerbaycan'da kurulan tüm bakanlıkların Nahcivan'da bakanlık düzeyinde örgütlenmiş temsilciliklerinin bulunduğunu görülmektedir. İllerde valiler yürütme yetkisini valiler yerine getirirken belediyeler ise yerel yönetim kurumları olarak il, köy ve kasabalarda oluşturulan yerel yönetim birimleri olarak örgütlenmişlerdir.

45 milletvekiline sahip olan parlamentoya başkanlık eden Yüce Meclis başkanı hem yasama hem de yürütmenin başıdır. Bu nedenle, başkan Nahcivan Özerk Cumhuriyeti'ni temsil eden en üst düzey yetkili kişidir. Yüce meclis Başkanının yasama alanında parlamento başkanı olması nedeniyle bir takım yetkilere sahip olmasının yanında yürütme alanında da Nahcivan Özerk Cumhuriyeti'nde genel olarak devleti temsil eden yetkili kişi olarak bütün devlet kurumlarına başkanlık etmektedir. Aynı zamanda Nahcivan Özerk Cumhuriyetini yurt dışında temsil etme yetkisine sahip olan Yüce Meclis başkanın diğer yetkileri şunlardır; Bakanlar kurulunun istifası hakkında kararı kabul etmek, kamu bütçesinde belirtilmiş harcama sınırları dâhilinde merkezi yürütme kurumları (bakanlıklar, devlet komiteleri, devlet ajansları) oluşturmak, Yüce Meclis tarafından kabul edilen kanunları onaylayıp yayınlamak, Nahcivan Özerk Cumhuriyeti'nde kurulan mahkemelere yargıç ve savcıları atamak, bazı suçluları affetmek, illere valilerin atanmak, vatandaşlık konularında kararlar almak, Nahcivan Özerk Cumhuriyetinde Azerbaycan Cumhuriyetinin askeri doktrininin uygulanması ile ilgili önerilerde bulunmak ve Güvenlik Şurasını oluşturmak gibi birçok yetkileri bulunmaktadır.

Nahcivan Özerk Cumhuriyeti Yüce Meclisinin ise bütçeyi onaylamak, Başbakanı göreve atamak ve görevden azletmek, sosyal ve ekonomik programları onaylamak, Bakanlar Kurulunun terkibini onaylamak ve güvenoyu vermek gibi yetkileri bulunmaktadır. Nahcivan Özerk Cumhuriyeti Bakanlar Kurulunun yetkileri, bütçesini hazırlayıp Yüce Meclise sunmak, bütçeyi yönetmek, sosyal ve ekonomik programları gerçekleştirmek ve Azerbaycan Cumhurbaşkanı'nın verdiği diğer görevleri yerine getirmektir.

Genel olarak Azerbaycan Cumhuriyeti Anayasası'nın kanunlarının, Cumhurbaşkanı'nın ferman ve kararlarının, Bakanlar Kurulu kararlarının Nahcivan'da kesinlikle uygulanma zorunluluğu vardır. Aynı zamanda Azerbaycan Cumhuriyeti Anayasasının 134. maddesinin 5. fikrasına göre Nahcivan Ö̈zerk Cumhuriyeti Yüce Meclisinin kabul ettiği kanunlar, Bakanlar Kurulu kararları, Azerbaycan Cumhuriyeti Anayasasına, Azerbaycan Cumhuriyeti kanunlarına, Cumhurbaşkanı'nın ferman ve kararlarına, Bakanlar Kurulu kararlarına uygun olmak zorundadır. Yukarıda anlatılanlarda görüldüğü üzere, Nahcivan'a verilen özerklik statüsü tarihi gelişmeler 1şı̆̆ında onun Azerbaycan'dan ayrılmasının önüne geçilmesi, daha doğrusu bu Türk yurdunun yabancıların işgalinden korunması amacını taşımaktadır.

\subsubsection{Yerel Yönetimler}

Sovyetler Birliği’nin dağılması ile sosyalist sistemden kurtulan orta ve doğu Avrupa ülkelerinde, yerel yönetimlerle ilgili mevzuat düzenlemeleri, genellikle ülkenin yönetici elitleri tarafından, Avrupa Yerel Yönetimler Özerklik Şartına uyumlu bir şekilde hazırlanmıştır (Güner, 1998:93 ). Yerel yönetimler konusunda Azerbaycan'da da benzer bir süreç yaşanmıştır. Nitekim kamu yönetiminde merkezi idare ile yerel idareler arasındaki ilişkileri ortaya koyan sitemler o ülkenin tarihsel süreci içerisindeki siyasi, idari, sosyal ve ekonomik yapısının bir sonucu olarak ortaya çıkmaktadır (Parlak, 2014:8-9; Kocaoğlu, 2015:33; Tan vd., 2013:530-531).

Azerbaycan Anayasasının 142. maddesine göre yerel yönetim kurumları il, köy ve kasabalarda yöneticilerinin seçimlerle belirlendiği belediyelerdir. Böylece, yerel yönetimler anayasal güvence altına alınmış ve tek basamaklı bir yerel yönetim sistemi benimsenmiştir. Fransa örneğinde olduğu gibi illerin yanı sıra köy ve kasaba tipi yaşayış yerlerine de belediye statüsü verilmiştir (Rehimli, 2005:180; 2009:67-68). 
Günümüz açısından Azerbaycan'da yerel yönetimler 1995 anayasasında düzenlenmiş olmasına ve iki yıl içinde hayata geçirilmesine hükmedilmesine rağmen, ilk seçimler 1999 y1lında yapılmış olup; 2000 yılı itibariyle faaliyetlerine başlamışlardır (Mecek, 2018:60). Son belediye seçimleri 23 Aralık 2019'da yapılmış olup bu seçimlerde 1606 belediyeye 15.156 belediye üyesi seçilmiştir.

Belediyelerin statüsü 1999 tarihli "Belediyelerin statüsü hakkında" yasayla belirlenir. Yasanın genel ilkeler kısmında yerel yönetim kavramı üzerinde durularak, bu kavramdan ne anlaşılması gerektiği açıklanmaktadır. Yasayla benimsenen yerel yönetim anlayışına göre, vatandaşlara yerel nitelikteki konuları kanunlar zemininde bağımsız ve serbest biçimde çözmek hakkı verilmektedir. Bu hakkı yerine getirme konusunda kanunda ifade edildiği biçimde genel, eşit, doğrudan seçim yöntemi uyarınca serbest, şahsi ve gizli oy ilkesine dayalı olarak seçilen belediyeler yetkili kılınmaktadır. Yasanın 2. maddesinde belediye, yasayla belirlenmiş arazi hudutları dâhilinde yerel yönetim biçimi olarak tanımlanmaktadır. Belediyeler kendi mülkiyeti olan (belediyeye ait olan taşınır ve taşınmaz emlak), yerel bütçe ve seçilmiş organlara sahip birimler olarak vasıflandırılmakta ve belediyelerin Azerbaycan Cumhuriyeti Anayasası ve bu yasayla yetkilendirildikleri yerel öneme sahip sorunları bağımsız şekilde çözecekleri ifade edilmektedir. Ayrıca belediyelerin eşitlik ilkesi temelinde kurulmaları ve faaliyet göstermeleri esastır.

Belediye tüzel kişiliğinin organları Anayasaya, Belediyelere Seçimler Hakkında Kanuna, Belediyelerin Statüsü Hakkında Azerbaycan Cumhuriyeti Kanununa ve kendi tüzüklerine dayanılarak kurulan belediye üyelerinden teşkil edilen seçimli yerel yönetim organlarıdır. Bu bağlamda, belediyeler ve onların organları devlet tüzel kişiliği sistemine dâhil değillerdir. Devlet organları ve devletin yetkili şahısları tarafından yerel yönetimin hayata geçirilmesine izin verilmez. Bu hükmün bir uzantısı olarak belediye üyelerinin yasama, yürütme ve yargı organlarında görev yapması engellenmektedir.

Belediyenin karar organı olan belediye meclis üyeleri çoğunluk yöntemi esasına göre genel, eşit, doğrudan seçim hukuku esasında serbest, şahsi ve gizli oylamayla seçilmektedirler. Üyelerin görev süresi 5 yıldır. Görev süreleri 5 yıl olan belediye meclis üyelerinin sayısı ilgili belediyenin kurulmuş olduğu yerleşim yerinin nüfusuna göre belirlenir. Yerel hizmetlerin sunulması temelinde belediye meclislerinin çok çeşitli görevleri söz konusudur. $\mathrm{Bu}$ görevler şunlardır: belediye tüzüğünün kabul edilmesi, belediye üyelerinin yetkilerinin tanınması, daimi ve geçici komisyonların oluşturulması, belediye başkanı ve başkan yardımcılarının seçilmesi, yerel vergilerin ve ödemelerin belirlenmesi, yasanın öngördüğü durumlarda üyelerin yetkilerinin yitirilmesine karar verilmesi, yerel sosyal savunma ve sosyal gelişme, yerel ekonomik gelişme ve yerel ekoloji programlarının kabul edilmesi, meclis gündeminin onaylanması, yerel bütçenin ve onun uygulanması hakkındaki raporların onaylanmasıdır (Rehimli, 2007:129-130; Rehimli, 2013:286).

Belediye meclisleri, yetkileri dâhilindeki işlerin önceden görüşülmesi, kabul ettikleri kararların hayata geçirilmesine yardım edilmesi, belediyeye bağlı olarak çalışan kuruluşların faaliyetlerinin denetlenmesi için daimi ve geçici komisyonlar kurulması gibi faaliyetler de yürütmektedirler. Bu komisyonlar belediye tüzüğü ve belediyenin daimi ve geçici komisyonları hakkında yönetmeliğe dayanarak faaliyet gösterirler. Daimi ve geçici komisyonlar belediye meclisine karşı sorumluluk taşırlar ve çalışmalarıyla ilgili Meclise bilgi verirler.

Belediyenin yürütme organı ise onun icra aparatıdır (yürütme aygıtıdır). Yürütme aygıtı çeşitli hizmet programlarını ile ekonomik ve sosyal programları hayata geçirmek için oluşturulan şube ve departmanlardan oluşmuştur. Bu şube ve departmanların başkanları yürütme aygıtına başkanlık eden belediye başkanı tarafından atanmaktadır. Ayrıca, belediyelerin yürütme aygıtlarındaki görevliler hukuki statüleri "Belediye Gulluğu Hakkında" Azerbaycan Cumhuriyeti Kanunu ile düzenlen belediye memurlarıdır. Bu kanunun 2. maddesine göre: "belediye gulluğu, yerel yönetim organlarının görevlerini yürütmek için bu organlarda devamlı meslek faaliyetidir". Belediye gullugcusu (memuru), yerel yönetim organlarında atama yoluyla görev yapan ve verdiği hizmet karşılığında ücret alan şahıstır. Belediye memurlarının ücreti belediye bütçesi tarafından karşılanmakta ve belediye meclisi üyeleri belediye memuru olarak değerlendirilmezler.

\section{KAMU İSTIHDAM DÜZENI}

Kamu istihdamı, kamu hizmetlerini yürütmek üzere bir kamu kurum veya kuruluşunda belli bir ücret karşılı̆̆ında, nitelikleri daha önce belirlenmiş bir kadro ve pozisyonda çalıştırılan kişilerin toplamını ifade etmektedir. Bu kişilerin hangi statülerde istihdam edilebilecekleri ilgili yasalar çerçevesinde belirlenmektedir (Güler, 2005:107). Azerbaycan'da kamu istihdamı "Devlet Gulluğu Hakkında" Kanunun5 14. maddesi

5 Burada Kanunun orjınal ismi kullanılmıştır. "Devlet Kulluğu Hakkında" veya "Kamu Hizmeti ile ilgili” Kanun olarak anlaşılmalıdır. 
temelinde devlet gullugçusu (devlet memuru), Emek Mecellesinin (İş Kanunu) 3. ve 4. maddeleri gereğince sözleşmeli kamu personeli ve işçilerden oluşmaktadır.

Azerbaycan Cumhuriyeti Emek Mecellesinin 6. maddesine göre burada bahsedilen kesim sivil kamu yönetimini ifade etmektedir. Askeri personeller, hâkimler, milletvekilleri ve seçimle belediye üyesi vasfını kazanmış kişiler kapsam dışında tutulmuştur. Tanım aynı zamanda kamu kurum ve kuruluşlarının ihale yoluyla gördürdükleri hizmetler sırasında istihdam edilen kişileri de kapsam dışında bırakmaktadır. Çünkü bu kişiler kamu hizmetine belli bir süre ve iş için özel hukuk hükümlerine uygun olarak özel hukuk tüzelkişisi üzerinden geçici olarak hizmet sunan şahıslardır. Bu durumda istihdamın sorumluluğu kamu kurumları üzerinde değildir (Güler, 2005:107).

"Devlet Gulluğu Hakkında" Kanunun 14. maddesinin 1.fikrasına göre; "Devlet gullugçusu (devlet memuru), bu kanunla belirtilmiş esaslara göre ücretli (ücret sadece devlet bütçesinden ödenmelidir) kamu hizmeti görevinde bulunan ve Azerbaycan Cumhuriyetine sadık olacă̆ına yemin eden Azerbaycan Cumhuriyeti vatandaşıdır". İdari görevlerde bulunan devlet memurları devletin yetkili şahıslarıdır. Diğer kamu görevlileri ise sözleşmeli personel olarak görev yapmakta ve "Devlet Gulluğu Hakkında" Kanunun hükümleri onlara uygulanmamaktadır. Genel olarak baktığımızda sözleşme rejimi, statü rejiminin tersine, kariyere değil iş tanımına dayalı ve personelin herhangi bir statü ya da iş güvencesine sahip olmadığı çalışma türüdür (Güler, 2005:89). Azerbaycan personel sisteminde de bu tür istihdam geniş uygulama olarak öngörülmüştür. Devlet memurları dışında, sözleşmeli personel olarak göreve alınan diğer kamu görevlileri (buraya doktorlar, ögretmenler, öğretim görevlileri, akademisyenler, hâkimler, polisler, savcılar vs. dâhildir) kuruluş ve işleyişi kendi yasalarıyla belirlenen hizmet alanlarını kapsamaktadır. Bunların statüsü ya da iş güvencesi ile ilgili hükümler kurumların kuruluş yasalarında ve Azerbaycan Cumhuriyeti Emek Mecellesinde (İş Kanununda) belirtilmiştir.

Azerbaycan Cumhuriyeti Emek Mecellesinin (İş Kanunu) 3. maddesine göre işçi, ilgili kurum başkanı ile yazılı sözleşme imzalayarak, ücreti ödenmekle çalışan özel şahıstır. Azerbaycan Cumhuriyeti Emek Mecellesinin (İş Kanunu) 4. maddesine göre sözleşmeli kamu personeli, ilgili kurum başkanı ile yazılı sözleşme imzalayarak, ücreti devlet bütçesinden ödenmekle çalışan şahıstır. Aşağıdaki tabloda farklı yasalara bağlı kamu görevlilerini ayrıntılı şekilde görebiliriz.

Tablo 1. Devlet Gulluğu Hakkında Kanuna, İş Kanununa ve Kendi Özel Kuruluş Yasalarına Bağlı Kamu Görevlileri

\begin{tabular}{|c|c|}
\hline $\begin{array}{l}\text { Devlet Gulluğu } \\
\text { Hakkında Kanunun } \\
\text { uygulandı̆̆ı kamu } \\
\text { görevlileri }\end{array}$ & $\begin{array}{l}\text { 1. Yürütme kurumlarının aparatında (yürütme aygıtında) görevli memurlar. } \\
\text { 2. Yasama kurumlarının aparatında (yürütme aygıtında) görevli memurlar. } \\
\text { 3. Yargı kurumlarının aparatında (yürütme aygıtında) görevli memurlar }\end{array}$ \\
\hline $\begin{array}{l}\text { Emek Mecellesinin (İş } \\
\text { Kanunu) uygulandığı } \\
\text { kamu görevlileri }\end{array}$ & $\begin{array}{l}\text { 1. Yasama, yürütme va yargı kurumlarının aparatları (yürütme aygıtı) dışında çalışan diğer kamu } \\
\text { personeli. } \\
\text { 2. Öğretmenler. } \\
\text { 3. Doktorlar ve diğer sağlık personeli. } \\
\text { 4. Öğretim üyeleri ve görevlileri } \\
\text { 5. Bilim adamları ve Azerbaycan Milli Bilimler Akademisi çalışanları } \\
\text { 6. Kamu kurum ve kuruluşlarında çalışan işçiler }\end{array}$ \\
\hline $\begin{array}{l}\text { Kendi özel yasaları } \\
\text { bulunan kurumların } \\
\text { kamu görevlileri }\end{array}$ & $\begin{array}{l}\text { 1. Hakimler-Mahkemeler ve Hakimler Hakkında Azerbaycan Cumhuriyeti Kanunu (10 Haziran1997) } \\
\text { 2. Prokuror (savc1)-Prokurorluk Organlarında Gullug (Hizmet) Geçme Hakkında Kanun (29 Haziran } \\
\text { 2001) } \\
\text { 3. Polis-Polis Hakkında Azerbaycan Cumhuriyeti Kanunu (28 Ekim 1999) } \\
\text { 4. Devlet Tehlikesizlik (Milli İstihbarat) hizmeti personeli-Milli Tehlikesizlik Hakkında Kanun (5 mart } \\
\text { 1992) } \\
\text { 5. Adliye personeli-Adliye Kurumlarında Gullug (Hizmet) Geçme Hakkında Kanun (26 Mayıs 2006) } \\
\text { 6. Gümrük personeli-Gümrük Mecellesi (10 Haziran 1997) } \\
\text { 7. Vergi personeli-Vergi Mecellesi (Ocak 2001) } \\
\text { 8. Dişişleri personeli-Diplomatik Hizmet Hakkında Kanun (8 Haziran 2001) }\end{array}$ \\
\hline
\end{tabular}

Tablodan görüldüğü gibi Devlet Gulluğu Hakkında Kanun, yasama, yürütme ve yargı organlarının aparatlarında (yürütme aygıtlarında) kamu hizmeti veren kamu görevlilerini kapsamına almaktadır. Askeri personeller, polisler, hâkimler, savcılar, devlete bağlı kurum ve kuruluşlarda çalışan işçiler, öğretmenler, doktorlar, öğretim 
görevlileri, bilim adamları ise kanunun kapsamı dışında bırakılmıştır. Azerbaycan silahlı kuvvetlerinde çalışan kamu görevleri askeriye ile ilgili mevcut yasalar kapsamında istihdam edilmektedirler. Devlete bağl diğer kurum ve kuruluşlarda çalışan ve kamu hizmeti gören kamu görevlilerine ise kendileri ile ilgili mevzuat ve Azerbaycan Cumhuriyeti Emek Mecellesinin (İş Kanunu) ilgili hükümleri uygulanmaktadır. Nitekim Azerbaycan Cumhuriyeti Emek Mecellesinin (İş Kanunu) 5. maddesinin 2. fikrasında şöyle denilmektedir;

"Bu kanun kamu görevlilerine, aynı zamanda savcı, polis ve diğer emniyet görevlilerine onlarla ilgili normatif hukuki kararlar dikkate alınarak uygulanmaktadır. Bu normatif hukuki kararlarda, bu görevlilerin emek, sosyal ve ekonomik haklart tümüyle belirtilmemişse bu kanunda belirtilen ilgili normlar onlara uygulanır".

Aynı zamanda "Devlet Gulluğu Hakkında" Kanunun 34. Maddesinde; "kamu görevlileriyle ilgili bu kanunda belirtilmeyen hususlar Azerbaycan Cumhuriyeti İs kanunuyla düzenlenir", ibaresi yer almaktadır.

Azerbaycan'da kamu görevlilerinin sayısal görünümü değerlendirildiğinde, Azerbaycan Devlet Statistika (İstatistik) Kurumu'nun 2020 yılı verilerine göre, iktisadi faal ahalinin say 5.190 .100 olduğu, bunlardan çalışanların 4.938.500, işsizlerin 251.600 olduğu anlaşılır. Çalışanlardan 914.500'ü devlet kurumlarında, 730.900'ü ise özel kurumlarda çalışmaktadır (https://www.stat.gov.az/source/labour/ 27.04.2020). 2019 yılının verilerine göre, devlette çalışanlardan 29.127'nin devlet gulluğçusu (devlet memuru) statüsünde olmuş, bu sayının \%28,2'i kadın, \%71,8'i erkek memurlardan oluşmuştur (http://www.stat.gov.az/source/labour/ 27.04.2020). Memurların \%57,2'inin taşrada, \%42,8'inin merkezde görevli oldukları Azerbaycan Cumhuriyeti Devlet İstatistik Kurumu raporlarından anlaş1lmaktadır (http://www.stat.gov.az/source/labour/_ 27.04.2020).

\section{KAMU PERSONEL SISTEMI}

Genel olarak bakarsak bağımsızlığın ilk yıllarında Azerbaycan'da mevcut olan kamu personel rejiminin özelliklerini şu şekilde özetlemek mümkündür;

1. Kamu Personeli Yönetim Sisteminin faaliyeti Cumhurbaşkanı'nın denetim ve gözetimi altında yürütülür. Kamu hizmetine giriş, yükselme, görevden alınma vs. tamamen devlet kurumları başkanlarının (bakanların, merkezi yürütme kurumu başkanlarının vs.) yetkisi dahilinde idi. 2007 yılından başlayarak devlet gullugçularının (memurlarının) sınavla işe alınması için TQDK (Talebe Kabulü üzere Devlet Komisyon) ve DQMK (Devlet Gulluğu Meseleleri üzere Komisyon) birlikte merkezi sinav sistemi uygulamaktaydı. 11 Nisan 2016 tarihinde belirtilen her iki kurum kapatılması ve bu kurumların görevlerini yürütecek yeni bir kurumun "Azerbaycan Respublikasının Devlet Imtahan Merkezi (Azerbaycan Cumhuriyeti Devlet Sinav Merkezi)" publik hukuki şahsın kurulması hakkında Azerbaycan Cumhurbaşkanı Ferman imzalamıştır.

2. Devlet kurumlarında mevcut olan personel idareleri (kadrlar teşkilatı) profesyonellikten uzak ilkeler esasında çalışmakta, kurumun ihtiyacı olan yetenekli elamanların liyakat ilkesi esas götürülerek göreve alınmalarına gerekli özen gösterilmemekte, kurum başkanının isteği doğrultusunda personel seçilmesi yoluna gidilmekteydi. Bazen göreve atamalar akrabalık, dostluk, bölgecilik ilişkileri de dâhil olmakla çeşitli yolsuzluklar yapılarak yürütülürdü. Son yıllarda "Korrupsiya ile Mübareze (Yolsuzlukla mücadele) Hakkında" Kanun (13 Ocak 2004, № 580-IIQ), "Devlet Gullugçularının Etik Davranış Gaydaları (Devlet Memurları Etik Kuralları)" Hakkında Kanun (31 Mayıs 2007, № 352-III Q) aracılığıyla ve yukarıda belirtilen kamu görevlerine girişte "Merkezi Sınav Sisteminin" uygulanması yolu ile bu durumun karşısının alınmasına özen gösterilmektedir.

3. Memur güvencesi istenilen düzeyde değildi. Bakan veya vali görevden alındığı zaman ilgili kurum çalışanlarının birçoğu görevden alınırdı. Şu anda bu durum genel olarak ortadan kaldırılmıştır. Ama çok yaygın olmasa da bazı görevler için hala geçerliliğini korumaktadır. Aynı zamanda konuyla ilgili mahkemelere yapılan başvurular çok azdır.

4. Devlet kurumlarındaki boş yerlere memur alınması için sınav ilanı verilmekle beraber, çoğu zaman devlet kurumu başkanının isteği doğrultusunda memur alımı gerçekleştirilmekteydi. Aynı zamanda bazı kurumlara memur alımı için yazılı sınav yapılmasına rağmen sözlü sınav veya mülakat zamanı bir sıra yolsuzlukların yapıldığı görülmekteydi. Bugün bu sorunların karşısının önemli ölçüde alındığı görülmektedir.

5. Kurumların çoğunda memurların görev yönetmeliği mevcut değildi. Kurumun bütün işleri bazı yetenekli memurlar tarafından yürütülmekte, diğer memurlar ise yukarıda da belirttiğimiz gibi yetenekleri esas 
alınmadan göreve atandıklarından görevlerini doğru dürüst yürütememekteydiler. Son yıllarda "Devlet Gulluğunu İdareetme (Yönetim) Şurası"'nın denetimi sayesinde bu durumun karşısı önemli ölçüde alınmıştır.

6. Memurluğa genç yaşlarda atanıp kariyer yapma olanağı ile ilgili belirli bir strateji yoktu. İktidarda olan partiye bağımlılık had safhada olduğu için parti içinde prestij ve güven memurlukta yükselmede esas belirleyici unsurdu. Bugün için ise bu durum azda olsa geçerliliğini korumaktadır.

7. Değerlendirme amacına uygun yapılmamakta, kayırma ve yolsuzluk olaylarının insanların şuurunda oluşturduğu olumsuzluklar yükselme için değerlendirmenin hiç bir öneminin olmaması kanısına varmaya sebep olmaktaydı. 10.02.2014 tarihinde Azerbaycan Cumhurbaşkanlığına bağlı Devlet Gulluğu Meseleleri üzere Komisyon tarafından onaylanan "Devlet Gullugçusunun Hizmet Fealiyetinin Giymetlendirilmesi” (Devlet memurunun değerlendirilmesi) Kuralları (Karar No: 021-Q) ile 2015 yılından geçerli olmak üzere kamu kurumlarında devlet memurlarının değerlendirilmesi süreci başlatılmıştır.

8. Kurumlarda hizmet içi eğitime gerekli önem verilmemekte, bazı kurumlarda ise eski Sovyetler Birliğinden kalma parti bağımlı ideolojik çerçevede hizmet içi eğitim kursları düzenlenmekteydi. Daha doğrusu memuru göreve hazırlayacak, görevde yükselmesi için gerekli bilgileri sunacak eğitim proje ve programları mevcut olsa bile etkinliği istenilen düzeyde değildi. Günümüzde ise memurların değişen koşullara adapte edilmesi için gerekli hizmet içi eğitim çalışmaları yapılmasına önem verilmektedir. 03.01.1999 yılında Azerbaycan Cumhurbaşkanlığına bağlı Devlet İdarecilik Akademisi kuruldu (Devlet İdarecilik Nezeriyyesi, 2010:32). Bu Akademi lisans, yüksek lisans ve doktora eğitimi ile beraber üst düzey yönetici eğitimi ve devlet memurlarına hizmet içi eğitim vermektedir. Şu anda birçok devlet kurumunun üst düzey yönetici eğitimi ve devlet memurlarının hizmet içi eğitim ihtiyacı bu kurum tarafından karşılanmaktadır.

Görüldüğü gibi Azerbaycan kamu personeli yönetim sisteminde bağımsızlığın ilk yıllarında bazı sorunlar mevcut olsa da günümüzde bu sorunların aşılması yönünde önemli adımlar atılmıştır. Azerbaycan kamu yönetimi sisteminde, özellikle de kamu personeli yönetim sisteminde yeniden yapılandırmaya en büyük destek Avrupa Birliğinin TACIS programı vasıtasıyla gerçekleştirilmiştir. 1990 yılının Aralık ayında Roma'da yapılan AB Zirve toplantısında, eski Sovyet Cumhuriyetlerini ekonomik reformlar hususunda desteklemek için karar alındı ve böyle bir AB desteğinin TACIS (Bağımsız Devletler Topluluğu'na Teknik Yardım) Programı aracıllğıyla gerçekleştirilmesi kararlaştırıldı ${ }^{6}$. Programın 3 temel hedefi vardı (Avrupa Birliği ve Türkiye, 1999:145). Bu hedefler şunlardır;

- Piyasa ekonomisi ve demokrasiye geçiş

- Her düzeyde ortaklığın ve ikili ilişkilerin geliştirilmesi

- Program kapsamındaki ülkelerin dünya ekonomisine entegrasyonu.

TACIS'in Azerbaycan'a yönelik projeleri 1991 yılından itibaren uygulanmaya başlanmıştır. 1998 yılına kadar program kapsamında yapılan yardım tutarı $75 \mathrm{mln}$. ECU olmuş, bu çerçevede gerçekleştirilen proje sayısı 170'e ulaşmıştı (Hüseynov, 2003:46).

Kamu personeli yönetim sisteminde reformların yapılmasına destek amacıyla 2002 yılının Mart ayında Azerbaycan Cumhurbaşkanlığına bağlı Devlet İdarecilik Akademisinde TACIS programını yürütecek ofis kuruldu. Bu programın asıl amacı aşağıda belirtilen konular hakkında çeşitli projeler hazırlayıp Azerbaycan Cumhurbaşkanlığı Administrasiyasına (İdaresine) sunmaktır. İlgili konular şunlardır;

1. "Devlet Gulluğu Hakkında" Azerbaycan Cumhuriyeti Kanununun uygulama stratejisinin hazırlanması.

2. İşe kabul, deneme, staj ve üst düzey yönetim görevlerine atamalara ilişkin yönetmeliklerin hazırlanması.

3. Devlet Gulluğunu İdareetme (Yönetim) Şurasının etkinliğinin artırılması ile ilgili önerilerin hazırlanması.

4. Devlet memurlarının merkezileştirilmiş informasiya merkezinin kurulması ile ilgili programın hazırlanmasi.

5. Devlet memurlarının eğitimi ile ilgili dokümanların hazırlanması

6 Programın ilkeleri ilk 3 yıllık dönem için 2157/91 sayılı Konsey Tüzüğü ile belirlenmiş, sonraki 3 y1llık dönem için 2053/93 sayılı Tüzükle düzenlenmiş, bu sürenin sona ermesiyle de 1276/96 sayılı Tüzük uyarınca uygulanmıştır (bkz. OJN165/1, 4.7.1996). 
"Devlet Gulluğu Hakkında" Kanun yürürlüğe girmeden önce devlet kurumlarında çalışanlara İş Kanununun hükümleri uygulanmaktaydı. Ama devlet sektörü ile özel sektör arasındaki farklar devlet memurlarının hukuki statüsü ile ilgili kanunların kabul edilmesini zorunlu kılıyordu. Ekonomik İşbirliği ve Kalkınma Örgütünün (OECD) hazırladığı raporda bu konu;

"Emek Mecellesi (İ̧̧ Kanunu) tüm çalışanlar için adil ve beraber hukuklu çalışma ortamı oluşturmak amacı taşıyor ve aynı zamanda onların hak ve yükümlülüklerini belirtiyor. Tabii ki, Emek Mecellesi (İş Kanunu), kalite standartları ve yöneticilerin verimlilik konusunda endişelerinden daha çok çalışanların resmi hukuklarını korumaya yöneltilmiştir",

şeklinde ifade edilmiştir. "Devlet Gulluğu Hakkında" Kanunun ve onun uygulanması için kabul edilmiş yasal düzenlemelerin asıl amacı yönetim sisteminin en önemli üyesi olan uzman personel ihtiyacının karşılanması, serbest şekilde üst düzey siyasi yöneticilere danışmanlık yapabilecek tecrübeli, güvenilir ve güçlü yöneticiler sınıfının oluşturulmasına katkıda bulunmaktır. Dünyanın her yerinde siyasiler kendi stratejilerini uzmanlık seviyesi yüksek, eğitilmiş memurlar vasıtasıyla uyguladıkları takdirde başarıya ulaşırlar. Aynı zamanda devletin uzun zamanlı stratejilerinin amacına uygun biçimde gerçekleştirilmesi için de, kamu hizmetinde siyasilerden bağımsız, kamu hizmetini yürütmekle görevli memur ordusunun bulunması gereklidir (OECD, 1996:6).

Hem Ekonomik İşbirliği ve Kalkınma Örgütünün (OECD), hem de Doğu Avrupa ülkelerinde devlet ve yönetimin yeniden yapılanmasının desteklenmesi (SIGMA) tarafindan verilen önerileri ele alırsak, Azerbaycan'da kamu yönetiminin tümünü kapsayan yeniden düzenlenme çalışmalarının bir parçası olarak personel rejimini konu alan 21 Temmuz 2000 tarihli 926-IQ-Nolu "Devlet Gulluğu Hakkında" kanun o zamana kadar mevcut olmayan kamu personeli yönetim sisteminin kurulması ve geliştirilmesi için önemli adım sayılabilir.

Altı bölümden oluşan Devlet Gulluğu Hakkında kanunun "Genel Esaslar” başlığını taşıyan ilk bölümü, kamu hizmetinin anlamı, amacı ve temel ilkelerini kapsamaktadır. İkinci ve üçüncü bölümlerde devlet organlarının sınıf ve tasnifleri yapılmıştır. Dördüncü bölüm devlet gullugçusunun (devlet memuru) tanımı, devlet gullugçularının hak ve yükümlülüklerini, uyması gereken yasakları içermektedir. Beşinci bölümde ise kamu görevlerine alınma usul ve şartları, hizmet şartları ve şekilleri, kamu görevinde ilerleme ve yükselmeler, kamu görevinin sona ermesi belirtilmiştir. Son bölümde çeşitli hükümler ve kanunun yürürlüğe girmesiyle ilgili maddeler yer almaktadir.

Kanunun genel amacı devlet memurluğunu sağlam ve sağlıklı statüye kavuşturmak, kamu hizmetine girişte sınav yöntemini uygulamak, ücret sistemini iyileştirmek, yükselme ve kadro sitemini nesnel ve adil temellere dayandırmaktır. Nitekim kanunun 1.maddesinde şöyle denilmektedir; "Bu kanun Azerbaycan Cumhuriyeti'nde devletle devlet memuru arasındaki ilişkileri ve devlet memurunun hukuki statüsünü düzenler".

Kamu Yönetiminde reformların yapılması üzere Avrupa Birliğinin TACİS Programının baş uzmanı Prof. Dr. Diter Shemanke'nin görüşüne göre bu kanun Avrupa Birliği'ne üye devletlerin uyguladıkları uluslararası standartların birçoğuna uygun olarak hazırlanmışıır (Devlet Gulluğu Konularına İlişkin Normativ Hukuki Aktlar, 2003:10). Bu, özellikle de Devlet Gulluğu Hakkında kanunun 4. maddesinde yer alan ilkelere aittir. Bu ilkeleri aşağıdaki gibi sıralayabiliriz;

1. Yasalara uygunluk.

2. Azerbaycan Cumhuriyetinde yasama, yürütme ve yargı organlarının yetki alanlarının belirlenmesi.

3. Kamu kurumlarının ve devlet memurlarının denetimi ve bunların faaliyet raporu sunması.

4. Üst düzey devlet kurumlarının ve yöneticilerin kendi yetkileri dâhilinde aldıkları kararların alt düzey devlet kurumları ve görevlileri tarafindan uygulanma zorunluluğu.

5. Tüm vatandaşların ve görevli kişilerin yetkili devlet memurlarının yasalara uygun olarak aldıkları kararları uygulama ve destekleme zorunluluğu.

6. Kamu görevine girmenin şeffaflığı.

7. Vatandaşların kamu görevine sınav veya mülakat esasında alınması.

8. Vatandaşların kamu görevlerine yerleştirilmelerinde yetenek ve eğitim düzeyleri, hizmetteki başarıları dışında hiçbir ayırım gözetilmemesi ve hukuki eşitliğin sağlanması.

9. Irkından, milliyetinden, cinsinden, dilinden, dininden asılı olmayarak ve sosyal durumuna bakılmaksızın tüm devlet memurlarının hukuki eşitliğinin sağlanması. 
10.Kamu görevlilerinin sosyal ve hukuki açıdan devlet tarafından korunması, bunların kendileri ve aileleri için şerefli yaşam düzeyi standardının sağlanması.

11.Devlet memurlarının etkili ve verimli çalışmasının sağlanması için onların uzmanlık düzeyinin yükseltilmesine, kurum içi ve kurumlar arası rotasyon yapılmasına gerekli özen gösterilmeli.

12.Kamu görevlilerinin yükümlülüklerini yerine getirmesi için sorumluluk taşıması, aynı zamanda kamu görevlilerinin hal hareketlerinden devlet kurumunun sorumlu olmas1.

Azerbaycan kamu personel rejimini düzenleyen "Devlet Gulluğu Hakkında" Kanunun önemli bir kaynak olmasına rağmen sorunları da mevcuttur. İlk olarak şunu belirtmemiz gerekiyor ki, kamu personel sistemini düzenleyen temel ilkeler "Devlet Gulluğu Hakkında" kanunda yeteri kadar açık şekilde yer almadığından uygulamada çok sayıda düzenleyici idari metinlere ihtiyaç duyulmaktadır. Şöyle ki, açıklık ve şeffaflık, yansızlık ve tarafsızlık, eşitlik ilkelerinin kanunda yer almasına rağmen kamu personel sisteminin esası sayılan liyakat ve kariyer gibi ilkeler kanunda açık olarak belirtilmemiştir. Oysaki yukarıda anlattığımız gibi devlet memurluğuna girişlerde ve yükselmelerde keyfi ve kişisel takdirlerin engellenmesi ve siyasi parti müdahalelerinin etkisinin azaltılması için bu ilkeler vazgeçilmezdir. Diğer bir taraftan Azerbaycan kamu personel sisteminin esas kanunu olarak kabul edilen "Devlet Gulluğu Hakkında" Kanun kamu personel rejimini tümüyle kapsamamaktadır.

Memur, işçi ve sözleşmeli kamu personeli arasındaki ayırım tam olarak açıklığa kavuşturulmamıştır. Yani, sadece memurların göreve başlarken yemin ettikleri, sözleşmeli personelin, yardımcı görevlerde bulunanların ise yemin etme zorunluluklarının bulunmadığı fark olarak ortaya koyulmuştur. Aynı zamanda kanunda birçok çözüme kavuşturulamayan konular, "başka kanunlarla veya yönetmeliklerle düzenlenecek" denilerek geçiştirilmeye çalışılmaktadır. Yine yukarıda belirtildiği gibi "Devlet Gulluğu Hakkında" Kanun sadece belirli görevlerde çalışan kamu personeline uygulanmaktadır.

Devlet Gulluğu Hakkında kanunun 2. maddesinin 2. fikrasına göre, kanun yasama, yürütme ve yarg1 organlarının yürütme aygıtlarında görevli personele uygulanmaktadır. Devletin diğer kamu kurum ve kuruluşlarında çalışan ve bu mevzuatın uygulandığı devlet memurları ile aynı hizmeti veren kamu görevlileri (kamu kurum ve kuruluşlarının yürütme aygıtları dışındaki personeli, öğretmen, doktor, akademisyen, vs.) kanunun kapsamı içine alınmamıştır. Aynı zamanda kanunun uygulanacağı kurum ve kuruluşlar esas itibariyle bir birinden farklı özellikleri olan kuruluşlardır. Bu bakımdan, farklı nitelikte olan kuruluşların personelini aynı kanun kapsamına almak veya bu kadar farklı mesleğe sahip personeli, bir kanun kapsamında toplamak ileride bazı sorunlar oluşturabilir.

Devlet Gulluğu Hakkında kanunun 31. maddesinde "Memurların Değerlendirmesi” konusunun yer almış olmasına rağmen, personel değerlendirmesinde esas alınacak ilkeler ve sicil raporlanı ile ilgili kapsamlı açıklama yoktur. Diğer bir sorun ise devlet memurlarının denetimi, onları denetleyecek kurum ve kuruluşlar, denetçiler, aynı zamanda denetim sisteminin işleme mekanizması hakkında açıklayıcı hükümler bulunmamaktadır (Rehimli, 2016:52). Bu söylediklerimiz daha doğrusu Azerbaycan'da devlet gulluğu ile ilgili yasal düzenlemelerin analizi şöyle bir fikir söylememize sebep olur ki, Azerbaycan kamu personel sistemini düzenleyecek, devlet memurları ile beraber diğer kamu personelini de kapsayacak yeni bir Devlet Personeli Kanununa ihtiyaç vardır. Bu kanun askeriye hariç tüm kamu görevlilerinin hukuki statüsünü düzenlemelidir.

Kanunda kamu personeli yönetim sisteminin ilkeleri, özellikle liyakat ve kariyer ilkeleri açık şekilde belirtilmelidir. Memur, sözleşmeli personel ve işçi tanımları anlaşılır şekilde kanunda yer almalı, bunlar arasında fark açık şekilde belirtilmelidir. Tüm kamu personelini içine alan sınıflandırma sistemi oluşturulmalıdır. Kanunda, hizmete girişte sınav ilke ve yöntemleri açık olarak belirtilmelidir. Genel hükümlerden kaçınılmalı ayrıntılara yer verilmelidir. Belirtilen sorunların çözümünde şu anda üzerinde çalışılan "Devlet Gulluğu Mecellesinin (Kodeksinin)" kabulü ve "Azerbaycan Cumhuriyeti nde Devlet Gulluğunun İnkişafina dair 2019-2025 yılları için Strateji”'de yer alan faaliyet planlarının uygulanmasının etkisi büyük olur. 


\section{SONUÇ}

Azerbaycan'da bağımsızlığın ilk yıllarından bu güne bağımsız, demokratik, laik ve ulus devlet kurma yolunda önemli adımlar atılmış, kamu yönetimi alanında birçok reform yapılmıştır. Özellikle demokratik ilkeler esasında çalışan bir siyasal rejimin ülke kalkınmasında önemli rol oynadığının anlaşılması siyasal ve yönetsel alanda yeniden yapılanmanı zorunlu kılmıştır. 1995 yılında kabul edilen Azerbaycan Cumhuriyeti Anayasasında kuvvetler ayrılığı ilkesinin benimsenmesi hakimiyetin kolları (yasama, yürütme ve yargı) arasındaki karşıllklı ilişkilerin bir-birini tamamlayan, demokratik ilkeler esasında kurulmasına temel oluşturmuştur.

Doğal kaynak yönünden zengin olan ülkelerin diğer ülkelerden farklı olan stratejik durumu sözkonusu. Bu, insiyatifinde olan zenginlikleri maksimum verimli kullanmakla yükümlü bulunan, aynı zamanda çeşitli zenginlik türlerinin amaca uygun ve dengeli olarak biçimlenmesini sağlayan uzun vadeli program ve projelerin uygulanmasından oluşur. Bilindiği üzere, doğal kaynakları zengin olan, fakat iş verimliliği, iç ve dış rekabet yeteneği ve genel ekonomik verimliliği yüksek olmayan ülkelerde tekyönlü gelişme, kısa sürede kaynakların tükenmesi ve sosyo-ekonomik gerilik, eşitsizliğin derinleşmesi gözlemlenmektedir. Dünya deneyiminden biliyoruz ki, makro-ekonomik düzeyde devletlerin kalkınma göstergesi olan ulusal servetin hem boyutu, hem içeriğinde önemli değişiklikler olmuştur. Öyle ki, gelişmiş devletlerin ulusal zenginlik göstergesi geçen XX yüzyıl boyunca defalarca artmış ve beşeri sermayenin gelişimine hız kazandırmıştır. Bu açıdan baktığımızda Azerbaycan 2009 yılında ekonomik geçiş dönemini sona erdirmiştir.

Son 10 yılda ekonominin çeşitlendirmesi, GSYİH-n 300 oranında artırması, en önemlisi, ekonominin petrol dışı sektörünün 2,4 defa yükseltmesi önemli başarı gibi değerlendirilebilir. Geçen sürede Azerbaycanın stratejik döviz rezervleri 30 defaya yakın çoğalarak 50 milyar dolara yaklaşmıştır. Yoksulluğun oranının \% 49'dan \%5'e, işsizliğin ise \%4.8'e gerilemesi gerçekleştirilen sosyal politikanın en büyük başarısı olarak değerlendirilmelidir (www.azstat.org). 2003 y1lında Azerbaycanda $1 \mathrm{~kg}$ petolden elde olunan enerji kullanılarak 2,1 dolar değerinde ürün ve hizmet üretiliyordu. 2009-da bu 7 dolara, 2011-de ise 7,22 dolara yükselmişdir (Alakbarov, 2012:57; Alakbarov, 2014:30). Bu ekonomik gelişmenin etkisi ile Azerbaycan'ın şehir ve bölgeleri, kasaba ve köyleri değişmiş ve modernleşmiş, nüfusun yaşam seviyesi, refahı yükselmiştir.

Ülke kendi önemli çokuluslu enerji ve iletişim projelerini başarıyla gerçekleştirmekle bölgenin ve Avrupa'nın ekonomik haritasını değiştirmeğe ve onu zenginleştirmeğe devam ediyor. Dünya Bankası tarafından 2020 yılında yayınlanan "Doing Business" raporunda en reformcu ülkeler siralamasında Azerbaycan ilk 20 ülke arasındadır (Azerbaycan Cumhuriyeti Nazirler Kabinesinin 2019 y1lı Faaliyet Raporu, 2020:11). Bugün Güney Kafkasya ekonomisinin yaklaşık \%80'i Azerbaycan'ın kontrolündedir. Kendi enerji güvenliğini sağlamış ülke Avrupa'nın enerji piyasasında önemli etkene dönüşmektedir. Ayrıca onun güvenliğine katkıda da bulunmaktadır. Yapılan araştırmalara göre, günümüzde bir takım Avrupa ülkelerinin enerji piyasasında Azerbaycan'ın hissesi \%30-40 düzeyindedir.

Siyasal sistemin yeniden yapılanmasına katkısından dolayı Azerbaycan'da yolsuzluğun önlenmesi açısından da önemli gelişmeler kaydedilmiştir. Ülkede son yıllarda gerçekleştirilen etkinliklerin serisine bir göz attığımızda, özellikle "Korrupsiya ya Karşı Mübareze ye (Yolsuzlukla Mücadele) dair 2012-2015 yıllar için Ulusal Eylem (Faaliyet) Planı", "Açık Hükümetin Teşvikine dair 2016-2018 ve 2020-2022 yıllart için Milli Fealiyet (Ulusal Eylem) Planlart"nı belirtmemiz gerekir.

Eylem planlarının uygulanması sonucunda hem devlet kurumlarının, kamu görevlilerinin çalışmaları, yönetim, hizmet alanları mükemmeleştirilerek, aynı zamanda resmi kurumların çalışmalarında toplumun katılımı ve saydamlık sağlanmıştır. Bunun yanı sıra, yeni kurumların oluşturulması aracılığıyla yönetim sisteminde bazı değişiklikler yapılmıştır ki, yolsuzluğa yol açan, rüşvet faktörünü mümkün kılan sebepler ortadan kaldırılsın. Buna örnek olarak "ASAN" Hizmet (Azerbaijan Service and Assessment Network) ve "Elektronik Hükümet" girişimleri gösterile bilir. Bu hizmetler vatandaş memnuniyetinin sağlanmasını, yolsuzluk ve rüşvet olaylarının ortadan kaldırılmasını, modern teknolojilerin uygulanmasını, kamu görevlisi-vatandaş ilişkilerinde yeni düşünce tarzının şekillendirilmesini hedeflemiştir.

Şu anda "ASAN Servis" merkezinde 10 devlet kurumu tarafindan 47 temel 320 den fazla yardımc yasal hizmet uygulanmaktadır. Aynı zamanda 2019 yılında 25 devlet kurumunun, 13 yerli yönetim biriminin 600-den fazla kamu hizmeti "ASAN hizmet endeksi” üzere değerlendirilmesi yapılmıştır (Azerbaycan Cumhuriyeti Nazirler Kabinesinin 2019 yılı Faaliyet Raporu, 2020:285-289). Gelecekte bu hizmetin coğrafyasının genişletilmesi ile birlikte, onun çeşitlerinin sayısının artırılması ve daha geniş alanlarda vatandaşlara hizmet gösterilmesi öngörülüyor. 
Genel olarak bakarsak belirttiğimiz tüm bu gelişmeler Azerbaycan Cumhuriyetinin modern bilimsel ve teknolojik yenilikleri kullanarak ulusal kalkınma stratejisi "Azerbaycan 2020: Geleceğe Bakış" hedeflerinin gerçekleştirilmesinin bir göstergesidir. Bu kalkınmanın sürdürülebilir olması yani çağdaş ve gelecek nesillerin çıkarlarına hizmet etmesi asıl amac olarak algılanmalı ve ülkenin gelişmesi için yaratıcı insan potansiyeli oluşturulmalıdır.

\section{KAYNAKÇA}

ABDUllaYEV, Cavid (2001), “Azerbaycan'da Anayasalaşma Süreci ve Benimsenen Sistemin Niteliği”, Avrasya Dosyası, Uluslararası İlişkiler ve Stratejik Araştırmalar Dergisi, S.7(1), ss.109-131.

ABDUllAYEV, Cavid (1998), “Azerbaycan Anayasası'nda Benimsenmiş Olan Hükümet Sistemi”, Yayınlanmamış Yüksek Lisans Tezi, Ankara Üniversitesi Sosyal Bilimler Enstitüsü, Ankara.

ALAKBAROV, Urhan (2012), "Sürekli Gelişme Aynı Zamanda İktisadidir, Ama Sadece İgtisadi Durumu Göstermez”, İdarecinin Sesi Dergisi, S.153, ss.56-57.

ALAKBAROV, Urhan (2014), Sürdürülebilir İnsani Gelişim ve Ekoloji Sivilizasyonun Esasları, Anadolu Üniversitesi Yayınları, Eskişehir.

ALlAHYAROVA, Tahire ve MEMMEDOV, Ferhad (2010), Azerbaycan'da Siyasi Partiyalar, SAM Yayınları, Bakü.

ASLANOV, Eldar (2007), “Azerbaycanda Kamu Yönetimi Reformu”, Yayınlanmamış Doktora Tezi, Ankara Üniversitesi Sosyal Bilimler Enstitüsü, Ankara.

AZERBAYCAN CUMHURBAŞKANLIĞI (2019), Azərbaycan Respublikasında Dövlət Gulluğunun İnkişafına Dair 2019-2025-ci Yıllar İçin Strategiya, https://president.az/articles/30841 (Erişim Tarihi: 10.03.2020).

AZERBAYCAN CUMHURBAŞKANLIĞI (2020), Açıq Hökumetin Teşvigine Dair 2020-2022-ci Yıllar İçin Milli Fealiyet Planı, Azerbaycan Cumhurbaşkanlığı, https://president.az/articles/35990 (Erişim Tarihi: 10.03.2020).

AZERBAYCAN CUMHURBAŞKANLIĞI'NA BAĞLI DEVLET İDARECILIIK AKADEMİSİ (2010), Devlet İdareçilik Nezeriyyesi, Elm ve Tehsil Yayınları, Bakü.

AZERBAYCAN NAZİRLER KABİNETİ (2020), Azerbaycan Cumhuriyeti Nazirler Kabinetinin (Bakanlar Kurulunun) 2019 Yılı Faaliyet Raporu, https://cabmin.gov.az/az/article/798/print/ (Erişim Tarihi: 05.04.2020).

AZERBAYCAN RESPUBLIKASI (1991-2001) (2001) , Azerneşr Yayınları, Bakü.

AZERBAYCAN RESPUBLIKKASI DEVLET STATISTIKASI KOMİTESİ (2020), Azerbaycan'ın Statistik Göstericileri, Seda Yayınları, Bakü.

AZERBAYCAN RESPUBLIKASI DEVLET STATISTIKASI KOMITESI (2019), Devlet Gullugçuları Statistik Mecmue, Azerbaycan Respublikası Devlet Statistikası Komitesi (Azerbaycan Cumhuriyeti Devlet İstatistik Kurumu) Yayınları, Bakü.

AZERBAYCAN TARİHI (1999), Azerbaycan Tarihi, Elm Neşriyatı Yayınları, Bakü, Cilt.3.

AZERBAYCAN TARİHI (2000), Azerbaycan Tarihi, Elm Neşriyatı Yayınları, Bakü, Cilt.4.

DEMİRLI, Mehman (2018), Şergin Çağdaşlık Mucizesi Azerbaycan Cumhuriyeti: Hukuk ve Demokratiya 1918-1920), Hukuk Yayınevi, Bakü.

DEMIROV, Mehman (1998), Организация Государственной Власти в Азербайджане 1918- 1920 гг. (Azerbaycan'da Devlet Hakimiyetinin Teşkili 1918-1920 Yılları), Astroprint, Odessa.

EKBEROV, Rahib (2009), Azerbaycan'ın Devlet ve Hukuk Tarihi, Ganun Yayınları, Bakü.

GÜLER, Birgül Ayman (1992), "SSCB'den BDT'ye Sovyet Tipi Devlet Örgütlenmesi", TODAİE Kamu Yönetimi Uzmanlık Programı Karşılaştırmalı Kamu Yönetimi Ders Notu, TODAİE Yayınları, Ankara.

GÜLER, Birgül Ayman (2005), Kamu Personeli: Sistem ve Yönetim, İmge Kitabevi, Ankara. 
GÜNER, Ayşe (1998), Orta ve Doğu Avrupa Ülkelerinde Yönetimler Arası Mali İlişkiler, Marmara Üniversitesi Maliye Araştırma ve Uygulama Merkezi Yayını, İstanbul.

HÜSEYNOV, Fuad (2003), Avrupa Birliyi-Azerbaycan İlişkileri, Yeni Avrasya Yayınları, Ankara.

İSMAYILOV, Süleyman (2013), Azerbaycan'da Devlet Gulluğunun ve İdareetme Sisteminin Geçmişi, Bugünü ve Perspektifleri, Oğuzeli Yayınevi, Bakü.

KELEŞ, Ruşen (1994), Yerinden Yönetim ve Siyaset, İmge Yayınları, İstanbul, 2.Baskı.

KOCAOĞLU, Mustafa (2015), "A Comparative Analysis within the Context of Central Government - Local Government Relationships in Local Governments at Turkey And Azerbaijan", International Journal of Business and Management Invention, S.4(4), ss.32-37.

MAHMUDOV, Yagub (2003), “Azerbaycan Devletçiliği (Tarihe Genel Bakış)”, Kafkas Üniversitesi Dergisi, S.11(Özel Say1), ss.61-135.

MAHMUDOV, Yagub (2007), "Eski Zamanlardan Íslam Dininin Kabulüne Kadarki Devrde Azerbaycan Devletçiliği”, E-Makale, ss.1-7, http://www.meclis.gov.az/tarix/tarix1.htm (Erişim Tarihi: 12.03.2014).

MECEK, Mehmet (2018), “Azerbaycan'ın Devlet Yapısı ve Taşra Yönetiminde Merkez - Yerel İlişkileri”, Bitlis Eren Üniversitesi Sosyal Bilimler Enstitüsü Dergisi, S.7(1), ss.51-77.

MEMMEDZADE, İlham, SETTAROV, Recep ve FERADOV, Tahir (2006), “Azerbaycan'da Vatandaş Cemiyetinin Inkişafi: Problemler, Alternatifler, Perspektifler", Gelecek 10 Yıl. Azerbaycan'da Demokratik İslahatların Başlıca İstikamet ve Maksatları, Adiloğlu Yayınları, Bakü.

OECD (1996), Civil Service Legislation Contents Checklist, OECD SIGMA Publisher, Paris.

ONAR, Sıddık Sami (1986), İdare Hukukunun Umumi Esasları, (Yazarın Kendi Yayını), İstanbul.

PARLAK, Bekir (2014), “Avrupa Birliği Perspektifinden Merkezi Yönetim - Yerel Yönetim İlişkileri”, TESAM Akademi Dergisi, S.1(1), ss.7-40.

REHIMLİ, Recep (2005), “Konstitutiyamızda Yerli Özünüidare Anlayışı (Anayasamızda Yerel Yönetim Anlayışı)", Azerbaycan Milli Bilimler Akademisi Meruzeleri, S.4, ss.179-182.

REHIMLİ, Recep (2006), Azerbaycan Kamu Personel Sistemi, Naturel Yayınları, Ankara.

REHIMLİ, Recep (2007), "Belediyelerin Görevleri", Nahçıvan Devlet Üniversitesinin Haberleri, Nahçıvan Gayret Neşriyatı, Nahçıvan, ss.127-130.

REHIMLİ, Recep (2009), Azerbaycan Respublikasının İdareetme Sisteminde Yerli Özünüidareler (Azerbaycan Cumhuriyetinin Yönetim Sisteminde Yerel Yönetimler), Elm Yayınları, Bakü.

REHIMLİ, Recep (2016), Azerbaycan Kamu Personel Yönetimi, Anadolu Üniversitesi Yayınları, Eskişehir.

REHIMLI, Recep, NEGIZ, Nilufer ve AKMAN, Elvettin (2013), "Azerbaycan Cumhuriyeti'nde Yerel Yönetimler", Dünyada Yerel Yönetimler: Örnekler - Uygulamalar (Ed. Murat Okcu, Hüseyin Özgür), Seçkin Yayınları, Ankara, ss.109-141.

TAN, Mehmet, ALIYEV, Pelin ve AYDIN, Abdullah (2013), "Sivil Toplum Kuruluşları-Yerel Katılım İlişsisi: Azerbaycan Örneği”, Kuramdan Uygulamaya Yerel Yönetimler ve Kentsel Politikalar (Ed. Yakup Bulut, Veysel Eren, Sedat Karakaya, Abdullah Aydın), Pegem Akademi Yayınları, Ankara, ss.526-536.

T. C. BAŞBAKANLIK (1999), Avrupa Birliği ve Türkiye, T. C. Başbakanlık DTM Yayını, Ankara, 4.Baskı. TORTOP, Nuri (1988), Mahalli İdareler, İlk-San Matbaası, Ankara, 3.Bask1.

ÜLKÜ, İrfan (2000), Bağımsızlıktan Sonra Azerbaycan, Doğan Kitapçılık Yayınları, İstanbul.

Azerbaycan Cumhuriyeti Anayasası (2020), Hukuk Edebiyyatı Yayınları, Bakü.

Azerbaycan Cumhuriyeti Bağımsızlık Beyannamesi (1991), Azerneşr, Bakü.

Azerbaycan Cumhuriyeti Emek Mecellesi (İş Kanunu) (2020), Hukuk Edebiyatı Yayınları, Bakü. 
Belediye Gulluğu Hakkında Azerbaycan Cumhuriyeti Kanunu (2019), Hukuk Edebiyatı Yayınları, Bakü.

Belediyelerin Statüsü Hakkında Azerbaycan Cumhuriyeti Kanunu (2019), Hukuk Edebiyatı Yayınları, Bakü.

Devlet Gulluğu Hakkında Azerbaycan Cumhuriyeti Kanunu (2020), Hukuk Edebiyatı Yayınları, Bakü.

Nahçıvan Özerk Cumhuriyetinin Anayasası (2020), Hukuk Edebiyatı Yayınları, Bakü.

Sovyet Sosyalist Cumhuriyetleri Birliğinin Anayasası (1978), Azerneşr Yayınları, Bakü.

Sovyet Sosyalist Cumhuriyetleri Birliğinin Anayasası (1988), Azerneşr Yayınları, Bakü.

www.azstat.gov.az (Erişim Tarihi: 03.03.2020).

https://www.stat.gov.az/ (Erişim Tarihi: 27.04.2020). 